\title{
Improving the energy performance of the typical multi-family buildings in Amman, Jordan
}

\author{
Jenan Abu Qadourah ${ }^{1 *} \mathbb{D}$, Ala'a M. Al-Falahat ${ }^{2}$, Saad S. Alrwashdeh² and Christoph Nytsch-Geusen ${ }^{3}$
}

\begin{abstract}
In this paper, the possibility of reducing the energy demand of the typical multi-family buildings in Amman, Jordan utilizing passive design strategies are investigated through a parametric simulation study. Firstly, the energy demand of the multi-family buildings under the typical practice is evaluated, after that several design strategies are proposed such as wall and roof insulation, shading device, ventilation, etc. The effect of each strategy on the multi-family buildings' energy demands is assessed alone and then in combination with the other strategies, to find the optimum solution to reduce the energy demand. This is beneficial for architects, engineers, and decisions makers involved in the design of energy-efficient multifamily buildings. The result proves that it's possible to reduce the annual energy demand by 53,71, and 78\% of the cooling, heating, and lighting, respectively, by introducing passive design strategies. Around $45 \%$ savings of the heating demand are achieved due to adding wall insulation. Regarding the cooling demand about $17 \%$, and $14 \%$ are saved due to applying a ventilated blind shading device and using a nighttime ventilation strategy.
\end{abstract}

Keywords: Energy performance, Passive design strategies, Residential buildings, Energy simulation, Multifamily building

\section{Introduction}

According to the international energy agency it is estimated that about $40 \%$ of the worldwide primary energy is consumed by the building field, more than half of this energy is utilized for heat, and cool spaces, as well as to prepare hot water. This energy is mostly generated by fossil fuels burning (IEA 2017), contributes to $\mathrm{CO}_{2}$ emissions, and has an impact on climate change (Koo et al. 2017; Alrwashdeh 2018a, b). It is also expected that the world's energy demand will increase in the future due to many factors such as population growth, high life quality, and increasing demand for building services (IEA 2017; Prieto et al. 2017). High energy consumption is caused

\footnotetext{
*Correspondence: jenan.abuqadourah@mutah.edu.jo

1 Department of Architecture Engineering, Faculty of Engineering, Mutah University, P.O Box 7, Al-Karak 61710, Jordan

Full list of author information is available at the end of the article
}

by heat gained and lost thru the building's envelope. Improving the energy efficiency in buildings is recognized as an attractive solution for mitigating the effects of this problem (Alrwashdeh and Alsaraireh 2018; Lambie and Saelens 2020).

Jordan is lacking indigenous energy resources and relies on imported gas and oil from foreign countries. According to the ministry of energy and mineral resources, Jordan imports around $97 \%$ of its energy needs in 2015, which causes a financial burden on the national economy (MEMR, 017). The energy demand has tripled in the last 15 years and is expected to continue at the same rate (NEPCO 2016; MEMR 2017, 2018). Moreover, in the past 50 years, Jordan has been a platform for accommodating multiple surrounding countries. Being in the center of the conflict zone, its political stability situation has been an attraction for the surrounding refugees. It has affected the population growth, which leads to an 
increase in housing demand and energy demand (Alnsour 2016). Furthermore, the residential sector accounts for the majority of energy consumption with up to $24 \%$ of the total energy consumed and about $42 \%$ of the total consumed electricity in the country (MEMR 2018). Moreover, during the last two decades, the building and construction sector has accelerated at a high rate, and $75 \%$ of the growth results from the residential stock (RSS 2007). Amman, the capital of Jordan, is the city where around $45 \%$ of the new constructions are taking place. The multi-family apartment buildings form $73 \%$ of the entire housing stock and more than $80 \%$ of all buildings (Younis 2017). Therefore, this study focuses on the multifamily buildings in Amman, Jordan.

Most Jordanian buildings give limited attention to considerations of climate and energy efficiency design. As the majority of the designers adopt a typical design without assuring passive strategies as being one of the major objectives in the building's design (Jaber et al. 2008; Johansson et al. 2009). Accordingly, many of these buildings do not offer their residents a comfortable indoor environment, which would necessitate increased cooling and heating demands, putting greater pressure on the Jordanian economy (Al-Hinti and Al-Sallami 2017; Bataineh and Al Rabee 2021).

In view of the situation described above (high rate of population growth, scarcity of local resources, high energy prices, and urbanization), one of the Mediterranean regions' priorities, and particularly in Jordan, is to enhance the building's energy efficiency. As a result, it is expected that increasing building energy efficiency would result in significant economic, social, and environmental advantages. Furthermore, because of the poor design of typical Jordanian buildings, it is expected that implementing passive design strategies will result in significant energy savings (Al-Hinti and Al-Sallami 2017).

Studies and researches related to the improvement of buildings' energy performance in the Jordan context are still very limited (Attia and Zawaydeh 2014; Bataineh and Alrabee 2018; Bataineh and Al Rabee 2021). However, many researchers around the world have focused their efforts on improving buildings energy performance (Cabeza et al. 2010; Yu et al. 2011; Lau et al. 2016; AlHinti and Al-Sallami 2017; He et al. 2019; Ali et al. 2020; Lambie and Saelens 2020; Liu et al., 2020; Bataineh and Al Rabee 2021; Ragab 2021). Wilhelm A. Friessa and Kambiz Rakhshanb investigated several passive strategies in the United Arab Emirates to combat the high climate. They discovered that optimal building orientations and the use of thermal insulation might save up to $20 \%$ on energy (Friess and Rakhshan 2016). Ingy El-Darwish and Mohamed Gomaa investigated Egypt's most important public building retrofit strategies, they recorded a final energy savings of 33\%. They found out that solar shading contributes the most to total energy savings, followed by double glazing. Also, wall insulation has been reported to play a substantial influence in minimizing energy loss and gain through the buildings envelope In Egypt's arid climate (El-Darwish and Gomaa 2017).

One of the important strategies for improving the building's envelope's energy efficiency is to apply insulation materials with high thermal resistance (Liu et al. 2020). In this respect, a study conducted under hot climate concluded that between 20 and 55\% of energy saving can be realized with thermal insulation and proper glazing type (Cabeza et al. 2010). Meral Ozel investigated the effect of wall orientation on the optimal thickness of wall insulation. He concludes that the appropriate thickness for the extruded polystyrene for the south-facing wall is $5.5 \mathrm{~cm}$, and the optimal thickness for the north, east, and west-oriented walls, was determined to be $6 \mathrm{~cm}$ (Al-Hinti and Al-Sallami 2017). Based on the life cycle cost concept, Jinghua Yu et al. established the most effective thickness of insulation for a residential building's roof in China. The optimal thickness ranged between $6.5 \mathrm{~cm}$ and $18.7 \mathrm{~cm}$ with a payback time ranging from 0.9 to 2.3 years (Yu et al. 2011).

Windows and shading devices design are important factors that can result in significant thermal heat gain or loss in buildings (Hee et al. 2015; He et al. 2019; Ragab 2021). It was determined that approximately $20-40 \%$ of a building's energy is lost through the windows (Hee et al. 2015). According to Zinzi et al., double glazing with a shading device in the gap increased total energy performance by dramatically lowering cooling loads while increasing the heating load (Zinzi et al. 2017). Allen and Elias investigated the effect of shading devices and glazing configurations on cooling energy demand for high-rise office buildings in Malaysia. They found that installing various shading systems on Low-E doubleglazed walls can result in annual cooling energy savings from $1.0 \%$ to $3.4 \%$ (Lau et al. 2016).

The study's novelty is that it recommends some important factors to be considered to reduce the energy consumption of typical multi-family buildings. Dynamic simulation software is used to calculate the energy consumption profiles for each of the proposed passive design strategies. Accordingly, the main objective of this study is to investigate the potential of using passive design strategies to reduce the energy demand of typical multi-family buildings in Amman, Jordan. To accomplish the research objective, the study investigates the following key questions: (1) How much energy is consumed in the typical multi-family buildings in Amman, which have hot dry summers and wet cool winters? (2) How can the energy performance of the multi-family buildings in Amman, 
Jordan be enhanced by improving the building envelope and implementing passive strategies?

The study's findings are likely to adopt an approach or guideline for energy researchers, architects, and policymakers seeking to understand the present situation of multifamily buildings and support designers in designing energy-efficient multi-family buildings based on passive design strategies that may increase Jordan's energy efficiency.

\section{Methodology}

In this paper, the potential of reducing the energy demand of the typical multi-family buildings in Amman, Jordan using architecture and passive design strategies are investigated through a parametric simulation study using IDA ICE 4.8 simulation software. Figure 1 presents the main steps adopted to reduce the building energy demand.

\section{IDA ICE simulation software selection}

IDA ICE 4.8 simulation software has been used to perform the dynamic multi-zone simulation to study the building energy demand. The software provides detailed results on the energy use and the parameters affecting the thermal behavior of the studied cases (EQUA 2018). Multi-zone models can be created, defining each room of the building with different conditions. Besides, it gives the possibility to import all common 2D and 3D CAD models used today in architecture. Geometry can be also imported from SketchUp or other geometry tools. A benefit of IDA ICE is the open-source code. This makes it possible for the user to understand the governing equations used for the simulation. One of the major benefits of IDA ICE is the 3D visualization of the building (EQUA 2018). The 3D-view can be used for presenting simulation results, which makes it easier for designers, engineers, and clients to visualize the consequences of design choices (Baranda and Sartori 2014; EQUA 2018).

IDA ICE is a well-proven building energy simulation software (Ryan and Sanquist 2012; Cornaro et al. 2017; Milić et al. 2018), in compared to other simulation tools, it can provide realistic estimations of buildings' energy consumption and interior climatic performance (Molin et al. 2011; Baranda and Sartori 2014; Vadiee et al. 2018). IDA ICE has been validated during development, and comparisons with other software and measurements have been conducted over the years by numerous studies, examples can be found in (Karlsson et al. 2007; EQUA Simulation AB 2010a, b; Molin et al. 2011; Hesaraki and Holmberg 2013; Liu et al. 2014; Liu et al. 2015; Cornaro et al. 2017; La Fleur et al. 2017).

\section{Base case model setup}

This section describes the input data to the IDA ICE 4.8 simulation software. The building body is created in SketchUp and then imported into IDA ICE. Each room is modeled as a separate space. All spaces have separate internal loads (occupancy, light, and equipment) with different schedules, to achieve realistic and accurate variable demands of the rooms according to the room type. The annual energy consumption is computed on an hourly basis $(8760 \mathrm{~h})$.

Input data for the modeled building, including building site surroundings, floor plans, and specifications of walls, roof, and windows are based on the typical apartment building practice in Jordan. Other input data such as

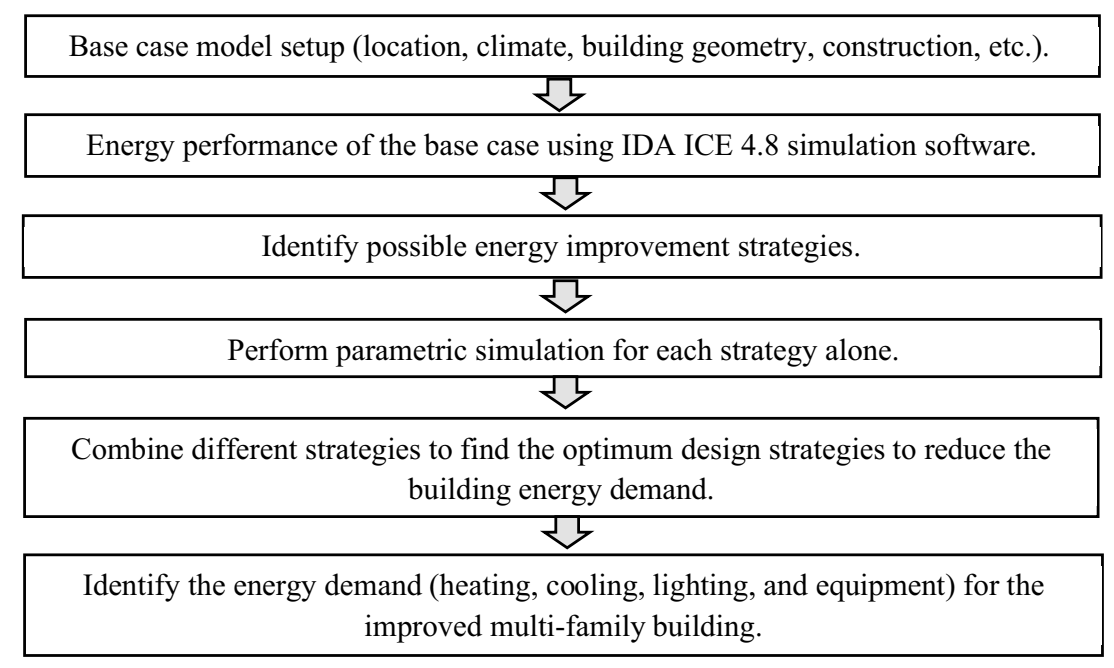

Fig. 1 The main steps used in this study to reduce the energy demand of typical multi-family buildings in Amman, Jordan 
lighting, occupants, and equipment's internal gains and schedule are based on standardized values or assumptions. The fundamental input data of the building is presented below:

\section{Location and climate}

The model used in the simulation is located in the city of Amman in Jordan. The latitude is $31^{\circ} 95^{\prime} \mathrm{N}$ and the longitude is $35^{\circ} 93^{\prime} \mathrm{E}$. The elevation considered is $788 \mathrm{~m}$ above sea level. Regarding the climate conditions, the "AMMAN JO" weather data file created by Meteonorm 7 software for Amman city is used in all simulation models. Jordan's climate is predominantly Mediterranean, with hot dry summers and wet cool winters (Hassouneh et al. 2014).

\section{Building site and orientation}

The simulated building is supposed to be in the most common residential urban areas, classified as $\mathrm{C}$ class urbanized context (Johansson et al. 2009; Awadallah 2015). All the surrounding buildings have a maximum permitted height in this zone, which is $15 \mathrm{~m}$. In IDA ICE only the adjacent buildings to the simulated case are simulated, as the other building does not have a significant shadowing effect on the energy demand of the simulated building, and this takes less time in the simulation process, see Fig. 2.

\section{Geometry, area, and zones}

The simulated multifamily building is based on a typical middle-class apartment that is found in most Jordanian residential building blocks. The model consists of 6 floors, 5 identical floors with 2 apartments on each floor, and the basement floor, the floor height is $3 \mathrm{~m}$. Each apartment is about $150 \mathrm{~m}^{2}$ total area, consists of a living room, a kitchen (including a dining area), 3 bathrooms, and three bedrooms. The typical floor plan is presented in Fig. 3.

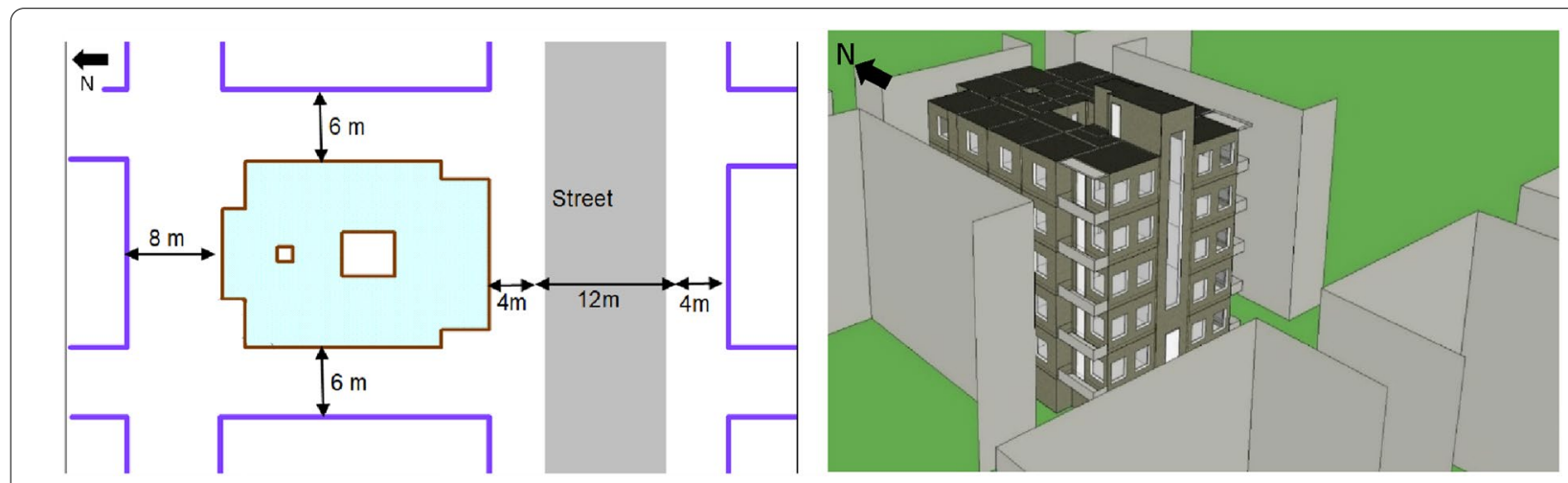

Fig. 2 (Left) Site plan and the assumed surrounding building modeled in IDA ICE 4.8. (Right) 3D view of the base case building and surrounding buildings modeled in IDA ICE 4.8

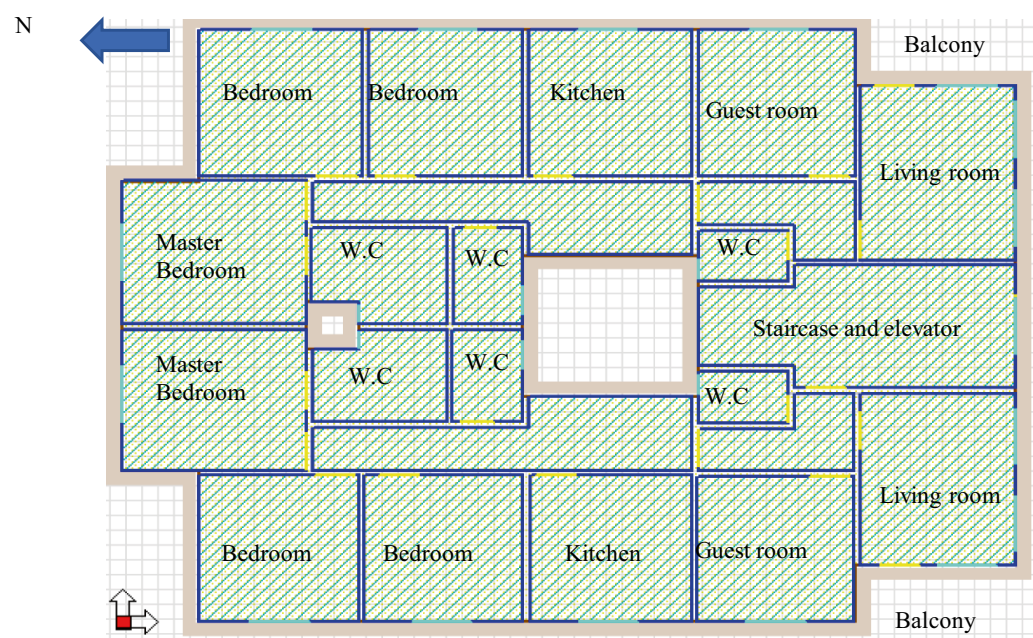

Fig. 3 Typical floor plan for the simulated multi-family building in Amman, Jordan. based on (Goussous, Siam and Alzoubi, 2014a) 
Table 1 Proprieties of construction used in the multi-family buildings in Jordan. Source of data: (Johansson et al. 2009)

\begin{tabular}{llcl}
\hline Building element & Materials & $\begin{array}{c}\text { Thickness } \\
(\mathbf{m m})\end{array}$ & $\begin{array}{l}\text { U-value } \\
\left(\mathbf{W} / \mathbf{m}^{2} \mathbf{K}\right)\end{array}$ \\
\hline Outer wall & Stone cladding & 50 & 2.47 \\
& Plain concrete & 100 & \\
& Hollow Block & 100 & \\
& Plaster & 25 & \\
Inner wall & Plaster & 25 & 2.88 \\
& Hollow concrete block & 100 & \\
& Plaster & 25 & \\
Internal floor & Cement tiles & 20 & 1.85 \\
& Low weight concrete & 30 & \\
& Concrete & 200 & \\
& Render & 25 & \\
& Tiling(cement) & 20 & 0.84 \\
Roof & Gravel & 30 & \\
& Waterproof Asphalt & 5 & \\
& Low weight concrete & 100 & \\
& Reinforced concrete & 200 & \\
& Render & 25 & \\
\hline
\end{tabular}

Table 2 The glazing properties and specifications for a building in Jordan. Source of Data: (Jaber and Ajib 2011)

\begin{tabular}{ll}
\hline Glazing properties & Specification \\
\hline Glass thickness & $6 \mathrm{~mm}$, single glazing \\
Solar transmittance & 0.83 \\
Visible transmittance & 0.89 \\
Window frame & Aluminum \\
U-value & $5.92 \mathrm{~W} / \mathrm{m}^{2} \mathrm{~K}$ \\
Solar heat gain coefficient & 0.87 \\
Integrated shading device & $\mathrm{No}$ \\
\hline
\end{tabular}

\section{Construction features}

The commonest types of construction, layer thickness, and U-values of the different building parts of the typical apartment building in Jordan have been presented in Tables 1 and 2.

In contemporary residential buildings, most windows in Amman build with single glazing and a simple rectangular hollow aluminum profile. Furthermore, this type of window offers a 50\% maximum opening (Jaber and Ajib 2011; Jäger et al. 2012). The specifications and characteristics of a single-glazed window are illustrated in Table 2 below.

\section{Parameters related to occupants}

Occupant number and schedule Regarding the occupant numbers and schedules, the below assumptions have been proposed according to the previous research (Attia and Al-Khuraissat 2016; Bataineh and Alrabee 2018) and the 2016 Population Census Report (Department of Statistics 2016).

It is reasonable to assume that each apartment is occupied by 6 persons, the parents and 4 kids, parents aged between 45 and 65 years, two adults aged between 18 and 25 years, and two children aged under 18 years (Department of Statistics 2016).

On weekdays, it is assumed that most of the occupants are out of the apartment at work, school, or university except for mothers, due to their roles as housewives. After 14:00, young children come home from school, while adults stay at work or university until 18:00, after which all family members tend to stay at home. Until 20:00, they are likely to stay in the living room, and then after this, the school kids will go to their bedrooms, and after 22:00 the other family member will go to their bedrooms with two members per room. However, at weekends, i.e., on Fridays and Saturdays, all occupants are assumed to be at home and most of the time in the living room and the dining area in the kitchen from 08:00 until 12:00. The occupancy schedules in a different zone in the apartment are illustrated in Fig. 4.

Metabolic rate It has been considered that the main activity level of each person is $1 \mathrm{MET}$, which corresponds to $58.2 \mathrm{~W} / \mathrm{m}^{2}$ of the body surface, which is the amount that an inactive person (one sitting person) is assumed to emit. However, in the bedrooms, the activity level is set $0.7 \mathrm{MET}$, which corresponds to a $72 \mathrm{~W} / \mathrm{m}^{2}$ of heat loss from the sleeping occupant (ASHRAE 2004).

Clothing insulation A value of $0.57 \pm 0.25$ CLO is used as the reference value in the performed simulations in IDA ICE. The CLO-value of 0.57 corresponds to the occupants wearing underpants, a shirt, and trousers (ASHRAE 2004).

\section{Equipment}

Regarding the equipment, it is assumed that each apartment has basic electrical appliances. The daily operating hours and schedules for each device have been estimated by the author, as illustrated in Table 3 below the specifications for the equipment are taken from the academic literature and guides (Nadel 2002; CIBSE 2006; ASHRAE 2004).

\section{Lighting}

The installed power and the distribution of the light units in the modeled apartment are presented in Table 4 
(a)

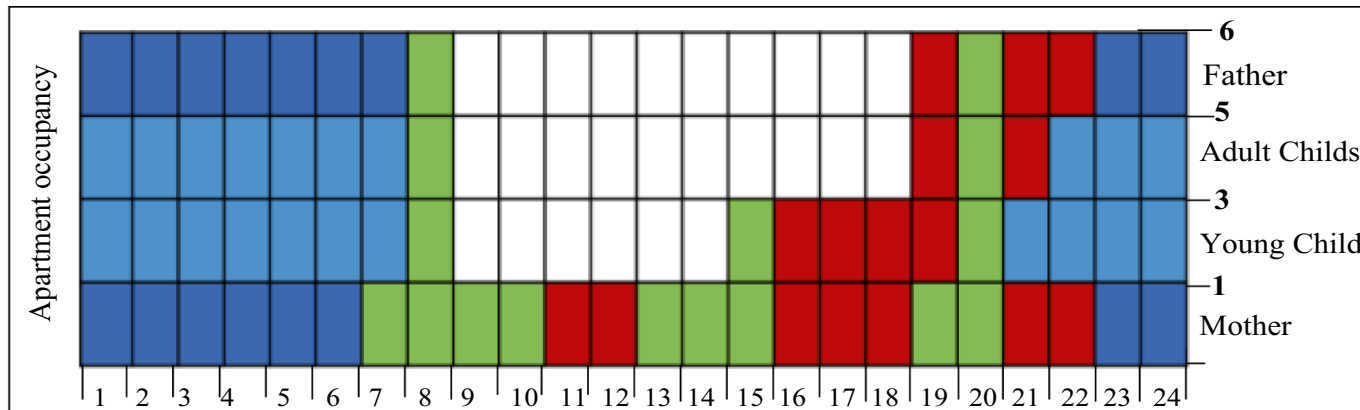

Time of day (hour)

(b)

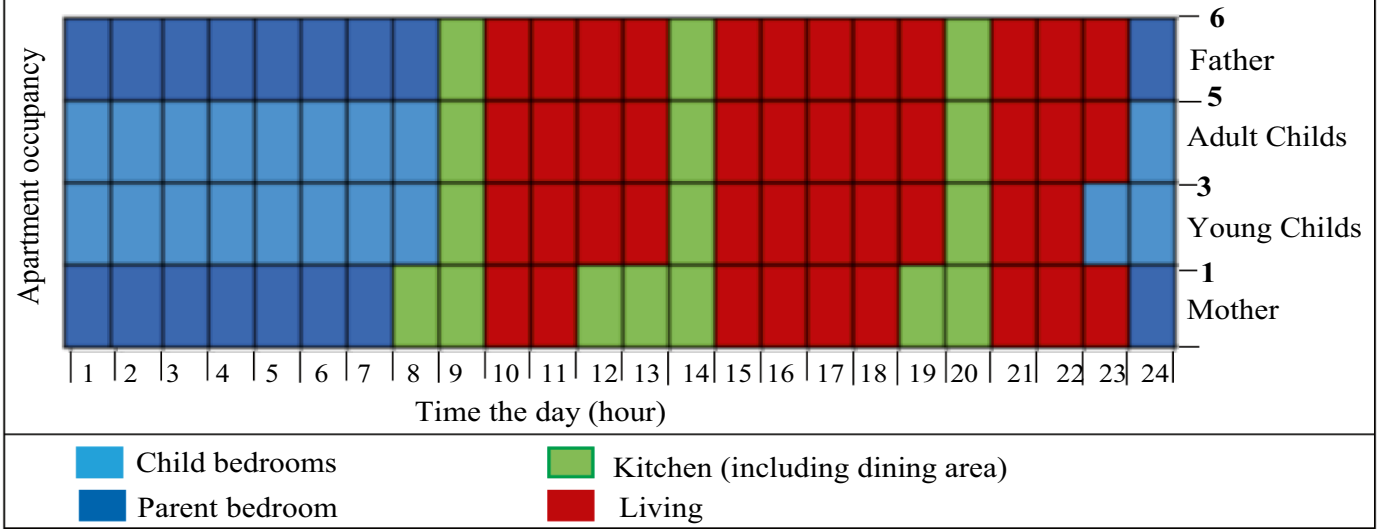

Fig. 4 Apartment occupancy schedules: a weekdays, b weekends

Table 3 The main appliances and their heat output in different zones in an apartment building in Jordan

\begin{tabular}{|c|c|c|c|c|}
\hline Zone & Appliance & $\begin{array}{l}\text { Heat output (W) } \\
\text { (operating) }\end{array}$ & $\begin{array}{l}\text { Heat output (W) } \\
\text { (standby) }\end{array}$ & Operating (hour/day) time \\
\hline \multirow[t]{5}{*}{ Living room } & Television & 315 & 20 & \multirow{2}{*}{$\begin{array}{l}6 \mathrm{~h} / \text { day } \\
11: 00-12: 00,16: 00-17: 00,20: 00-22: 00\end{array}$} \\
\hline & Receiver & 140 & 5 & \\
\hline & Iron & 1500 & - & $\begin{array}{l}2 \text { h/day } \\
\text { Saturday: 10:00-12:00 }\end{array}$ \\
\hline & Vacuum cleaner & 630 & - & $\begin{array}{l}0.15 \mathrm{~h} / \text { day } \\
10: 00-10: 15\end{array}$ \\
\hline & 2 laptops & 120 & & $\begin{array}{l}2 \mathrm{~h} / \text { day } \\
\text { 20:00-22:00 }\end{array}$ \\
\hline \multirow[t]{4}{*}{ Kitchen } & Refrigerator & 350 & 10 & 24 h/day \\
\hline & Washing machine & 512 & 10 & $\begin{array}{l}2 \text { h/week } \\
\text { Saturday: 8:00-10:00 }\end{array}$ \\
\hline & Kettle & 1200 & 5 & \multirow{2}{*}{$\begin{array}{l}0.15 \mathrm{~h} / \text { day } \\
\text { 6:00-6:05, 13:00:13:05 } \\
\text { 18:00:18:05 }\end{array}$} \\
\hline & Microwave & 800 & 5 & \\
\hline \multirow[t]{2}{*}{ Bedroom (in each) } & Laptop & 60 & - & $\begin{array}{l}1 \mathrm{~h} / \text { day } \\
21: 00-22: 00\end{array}$ \\
\hline & Hairdryer & 250 & - & $\begin{array}{l}1 \text { h/day } \\
\text { 6:00- 7:00 }\end{array}$ \\
\hline
\end{tabular}


Table 4 Electric power for the apartment lighting, source of data:(Al-Salaymeh et al. 2010)

\begin{tabular}{lll}
\hline Room & Number of lights unites & Power (W) \\
\hline Guest room & 1 chandelier (6 lamps 60 W each) & 360 \\
Kitchen & $\begin{array}{l}\text { 2 light bulbs 60 W each and 1 fluores- } \\
\text { cent lamp }\end{array}$ & 160 \\
3 bathrooms & 3 light bulbs & 180 \\
3 bedrooms & 2 bulbs each & 360 \\
2 corridors & 2 bulbs each & 240 \\
Living room & 1 chandelier (6 lamps 60 W each) & 360 \\
\hline
\end{tabular}

Table 5 Lighting setpoints used in the simulated model based on a recommended light level by (CIBSE 2013)

\begin{tabular}{llllll}
\hline & $\begin{array}{l}\text { Living } \\
\text { room }\end{array}$ & Kitchen & Bathroom & Bedroom & corridors \\
\hline $\begin{array}{l}\text { Light level } \\
\text { (lux) }\end{array}$ & $100-300$ & $150-300$ & $150-200$ & $100-150$ & $100-150$ \\
\hline
\end{tabular}

below, based on the previous research conducted by ALSalaymeh (Al-Salaymeh et al. 2010).

The artificial lighting is controlled according to the "setpoints and schedule" strategy. The setpoints are considered according to the recommended light values in lux by CIBSE lighting code, see Table 5 (CIBSE 2013). For example, in the living room when the indoor daylight intensity is higher than $300 \mathrm{~lx}$, artificial lighting is turned off. On the contrary, artificial light is starting to work when the natural light is lower than $100 \mathrm{~lx}$. Regarding the schedule, in the living room, guest room, and kitchen zones the lighting schedule follows the presence of the occupants. However, in the bedrooms, it is assumed that the occupant turns the light on (when the light level is below the setpoints) $2 \mathrm{~h}$ in the early morning during the weekdays and two hours daily in the night, the lighting schedules in the bedrooms are presented in Fig. 5. For the corridors, the light schedule is set on from 5:00-7:00 and 20:00-23:00.

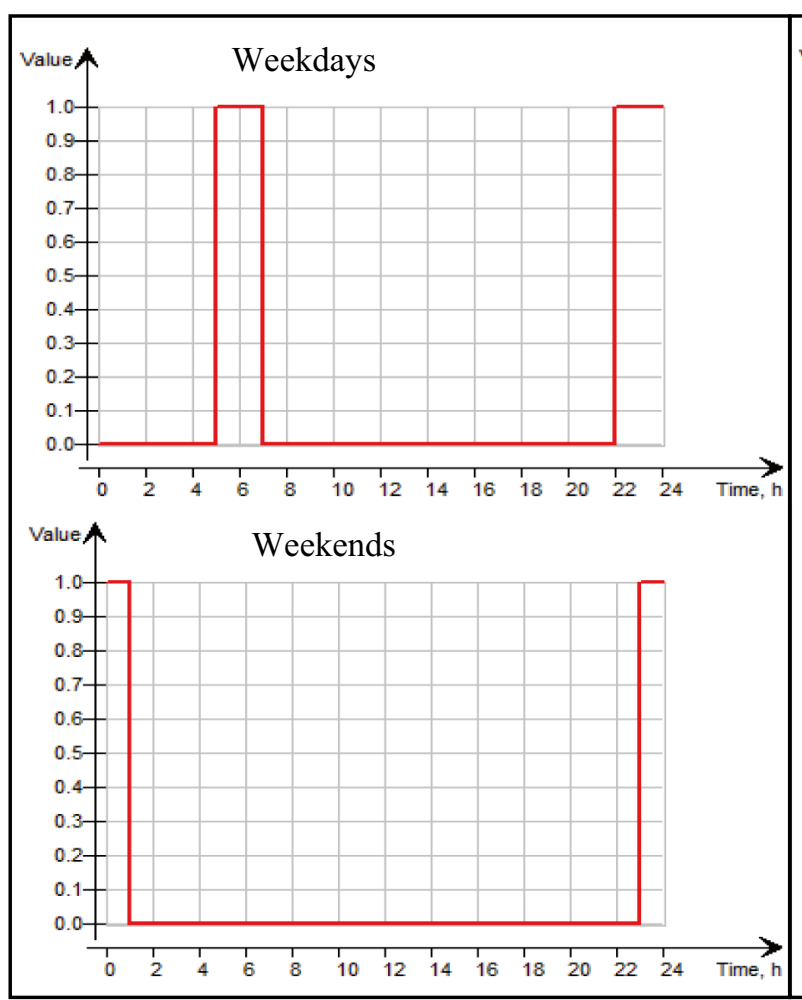

(a)

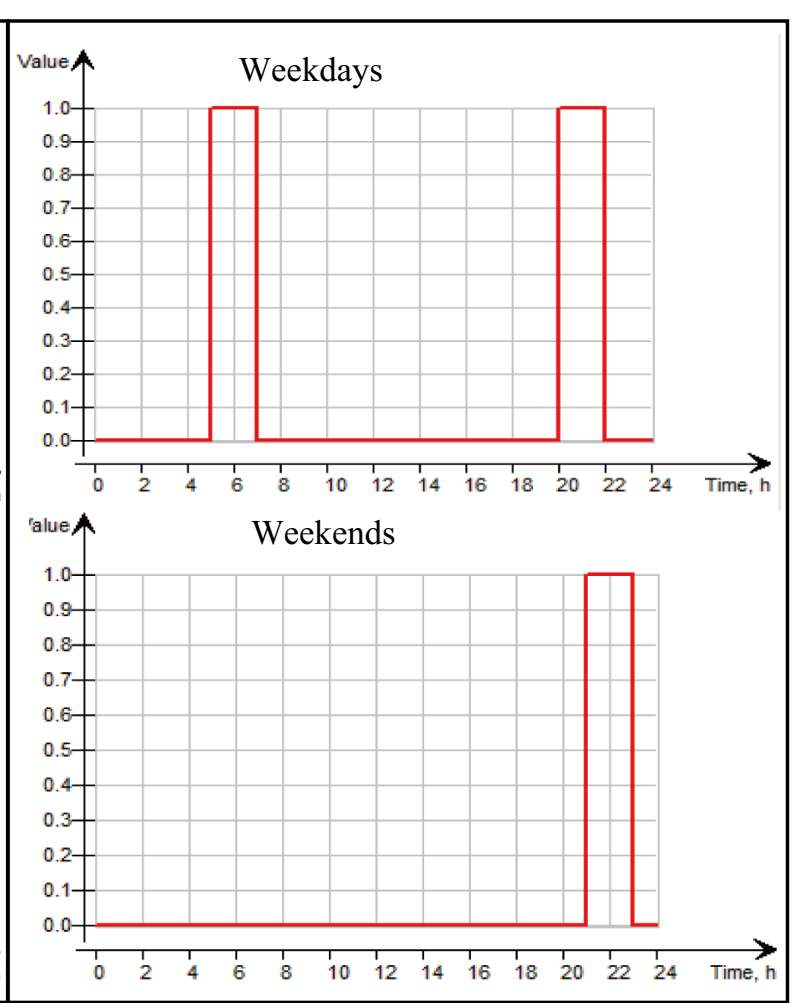

(b)

Fig. 5 Bedroom's lighting schedules: a master bedroom, $\mathbf{b}$ children's bedrooms 


\section{Infiltration}

The assumed infiltration rate is $0.5 \mathrm{ACH}$ (air change per hour) at a differential pressure of $50 \mathrm{~Pa}$ (Pascal), based on ASHRAE Standard 62.2- 2016 (ASHRAE, 2016).

\section{Ventilation}

Regarding the ventilation, in winter, the occupants revealed that opening windows is not desirable except just for fresh air intake for a short time in the morning. For simulation analysis reasons, this limited-time was approximated to be one hour in the morning (from 8:00 to 9:00). On the other hand, in summer, the windows are opened if cooling is needed, and the occupants are at home.

As shown in Fig. 6, the opening and closing of the windows are modeled using an on/off temperature control macro with a dead band of $4{ }^{\circ} \mathrm{C}$. This means that the windows would open when the room temperature raised $2{ }^{\circ} \mathrm{C}$ above the setpoint temperature, and close when it is dropped $2{ }^{\circ} \mathrm{C}$ under the setpoint temperature. In this case, the setpoint temperature is set $25{ }^{\circ} \mathrm{C}$ ensuring windows open at $27{ }^{\circ} \mathrm{C}$ and closing at room temperature under $23{ }^{\circ} \mathrm{C}$. It is also connected to the outdoor temperature, as the windows would open if the outdoor temperature is only under the indoor temperature and it is connected with the zoning occupancy. Then it is multiplied by a fresh air schedule from 8:00 to 9:00 in winter.

Regarding the ventilation in the bedrooms, the windows are assumed to be open every day for fresh air, for one hour from 08:00 to 09:00.

\section{Heating and cooling units}

An "ideal heater" and "ideal cooler" are assumed as the devices for heating and cooling the rooms in IDA-ICE. Regarding the heating and cooling setpoints, according to ASHRAE comfort standard 55, the recommended temperature range of residential buildings, where the relative humidity is $60 \%$, is between $23{ }^{\circ} \mathrm{C}$ and $26{ }^{\circ} \mathrm{C}$ in summer and $20^{\circ} \mathrm{C}$ and $23^{\circ} \mathrm{C}$ in winter (ASHRAE, 2004). But summer humidity in Amman, Jordan, is less than 50\%, as the country is mainly characterized by hot and dry weather. Therefore, summer temperatures range from $23.5{ }^{\circ} \mathrm{C}$ to $27^{\circ} \mathrm{C}$, assuming that relative humidity is $30 \%$.

In this research, the proposed setpoints are $20{ }^{\circ} \mathrm{C}$ for heating and $27^{\circ} \mathrm{C}$ for cooling. The advantages of a higher upper limit $\left(27^{\circ} \mathrm{C}\right)$ during the summer and lower limit during the winter season $\left(20^{\circ} \mathrm{C}\right)$ are less thermal shock on entering or leaving a building, and less energy needed for air-conditioning.

\section{Energy performance of the base case model}

In this section, the base case building energy demands, and energy balance is estimated by IDA ICE simulation software, based on the above-mentioned input conditions, to evaluate the energy efficiency of the typical apartment buildings in Amman, Jordan, and suggest possible solutions to reduce it is energy demand. In the discussion below, the apartment (Apt.1) refers to the apartment on the east side and apartment 2 (Apt.2) refers to the west side of the building.

The total annual energy demands for all the apartments in the base case residential building are 27,545

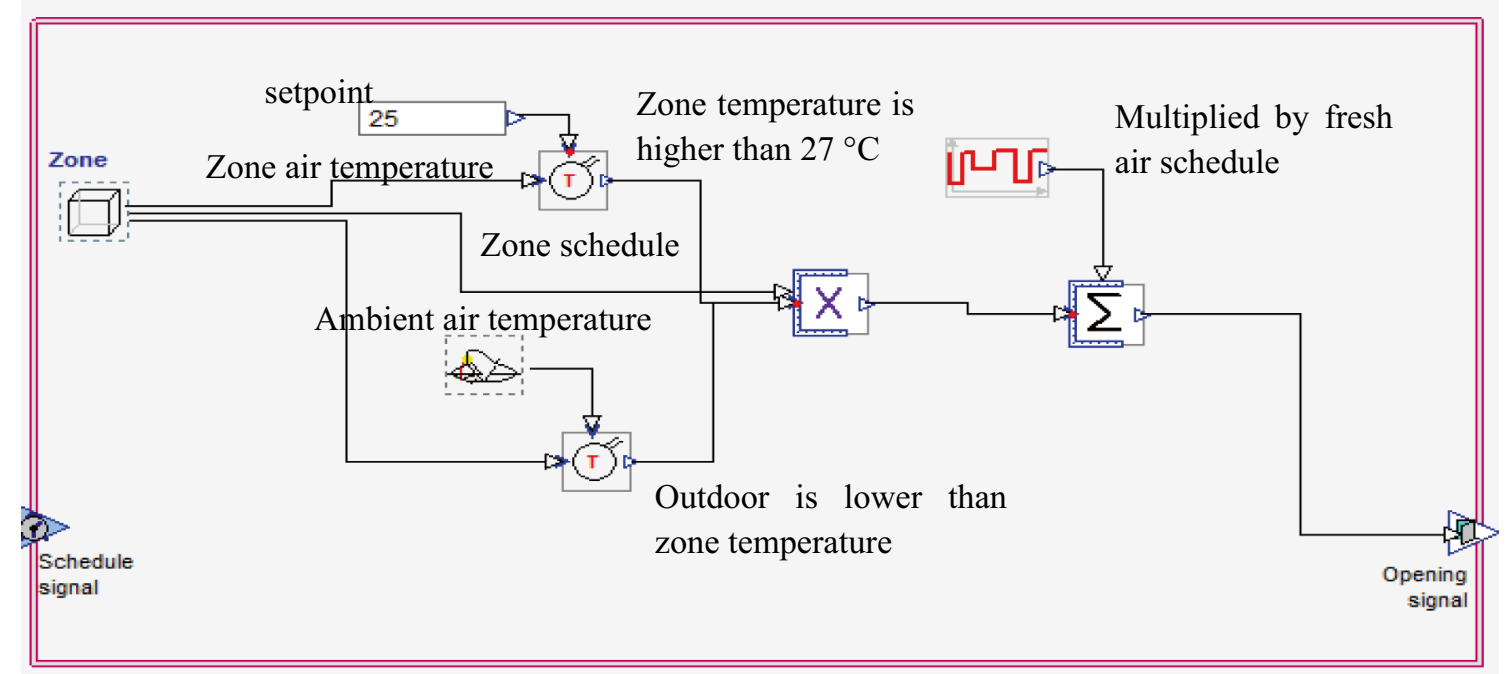

Fig. 6 Windows opening control macro in IDA-ICE used in simulations. The window are opened if the zone temperature exceeds the cooling setpoint $\mathrm{tcool}+\Delta \mathrm{t} / 2$, and the outdoor temperature is lower than the room temperature. The window are closed when the zone temperature drops below tcool $-\Delta \mathrm{t} / 2$. $\Delta \mathrm{t}$ is defined as dead band value 


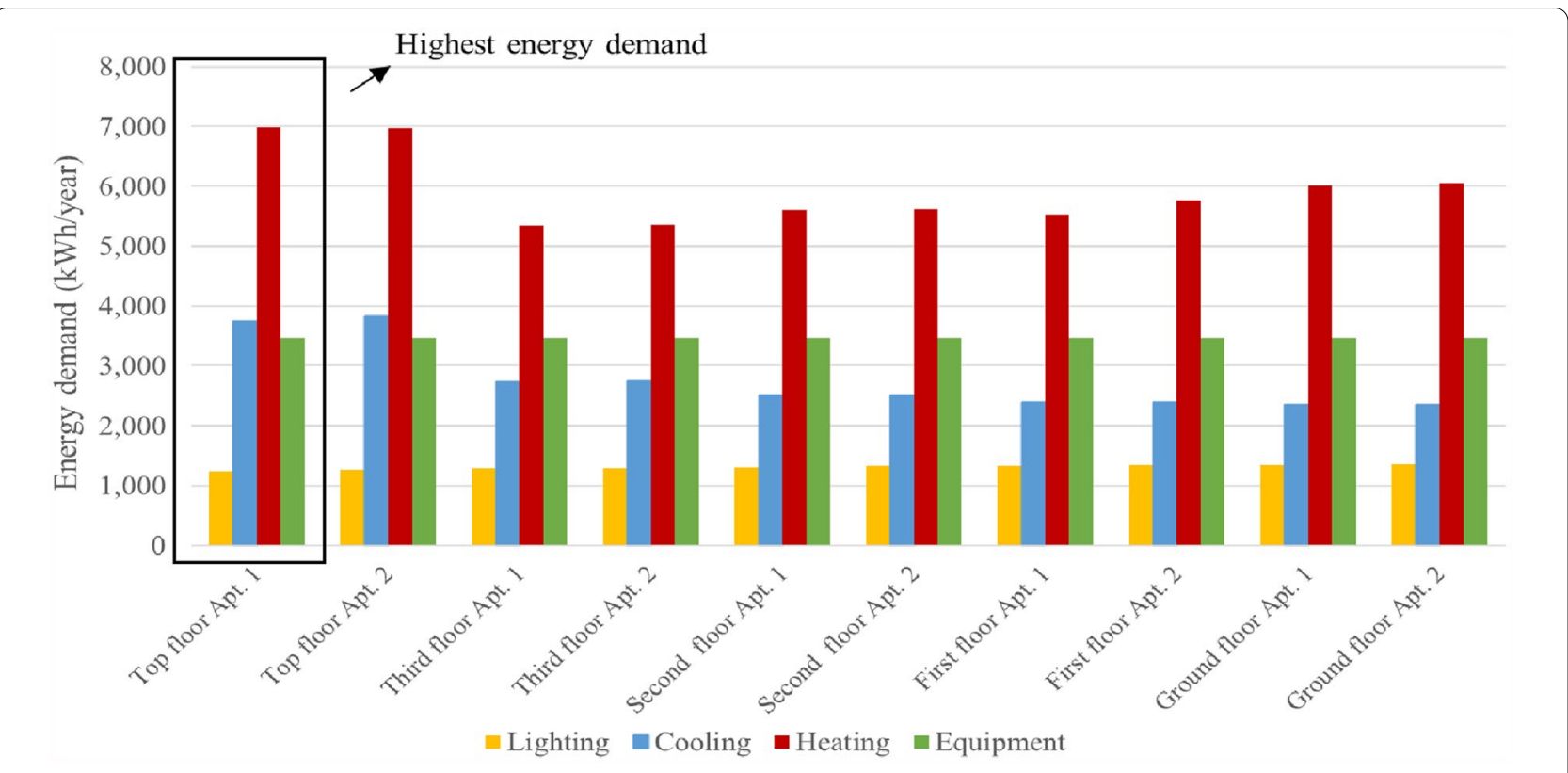

Fig. 7 Annual energy demand for different apartments of the base case model representing a typical multifamily building in Amman, Jordan

$\mathrm{kWh} /$ year for cooling, 59,247 $\mathrm{kWh} /$ year for heating, $34,552 \mathrm{kWh} /$ year for equipment and 12,350 kWh/year for lighting. Figure 7, illustrates the energy demand, including heating, cooling, lighting, and equipment of each apartment on different floors. According to the simulation findings, both cooling and heating demands are present, however, the heating demand is dominant, this is consistent with the findings of Jaber et al. 2008., as they revealed that the majority of the energy consumed in the typical residential stock is for space heating (Jaber et al. 2008). It is also clear that the topfloor apartments have the highest heating and cooling energy demand among all other apartments.

For further analysis in terms of monthly energy demand and energy balance, top floor Apt.1 is selected, assuming it is the critical case.

Figure 8 illustrates the heat transmission losses and gains through the building envelope elements and Fig. 9

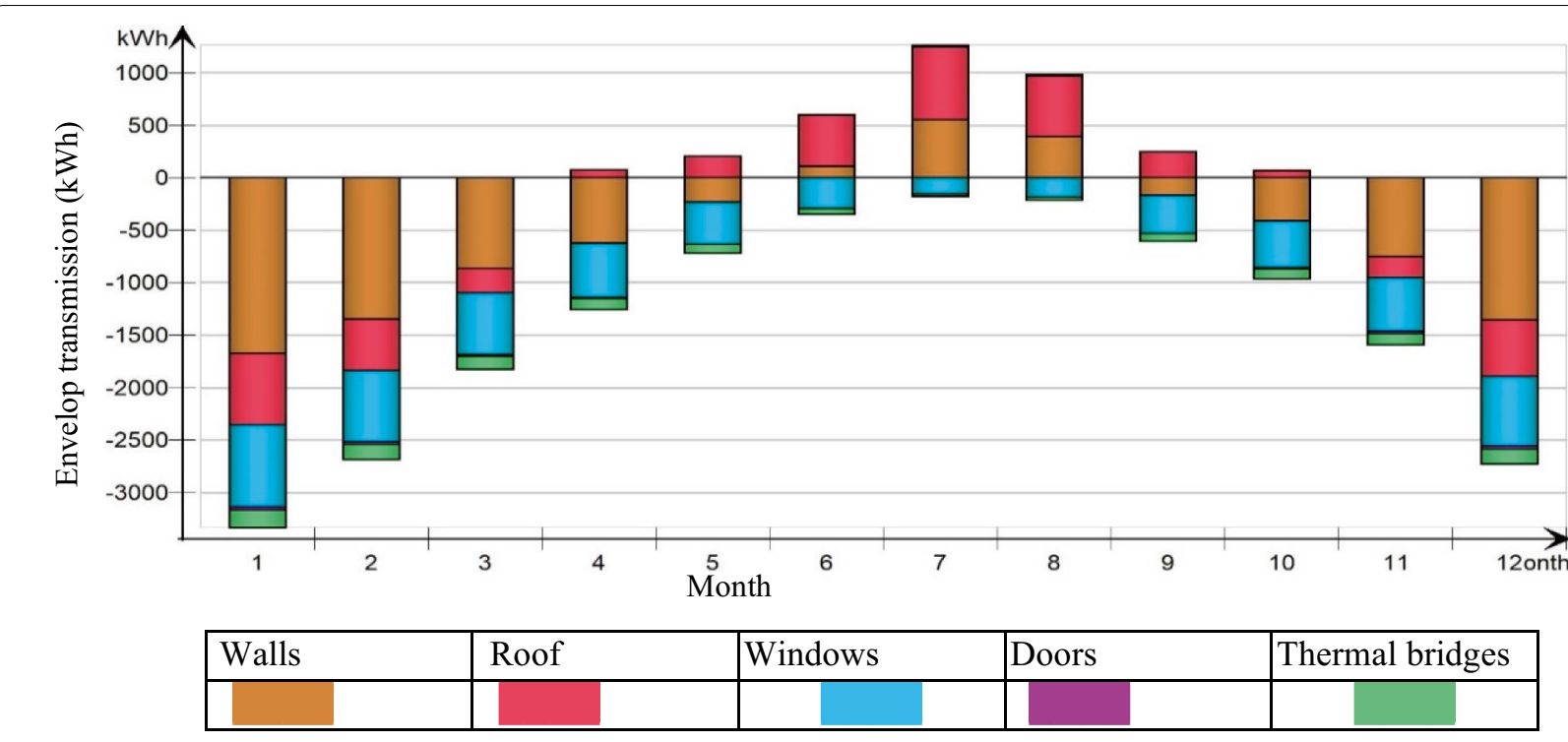

Fig. 8 Monthly envelop transmission results for the base case top floor apartment 1 in residential building in Amman, Jordan 

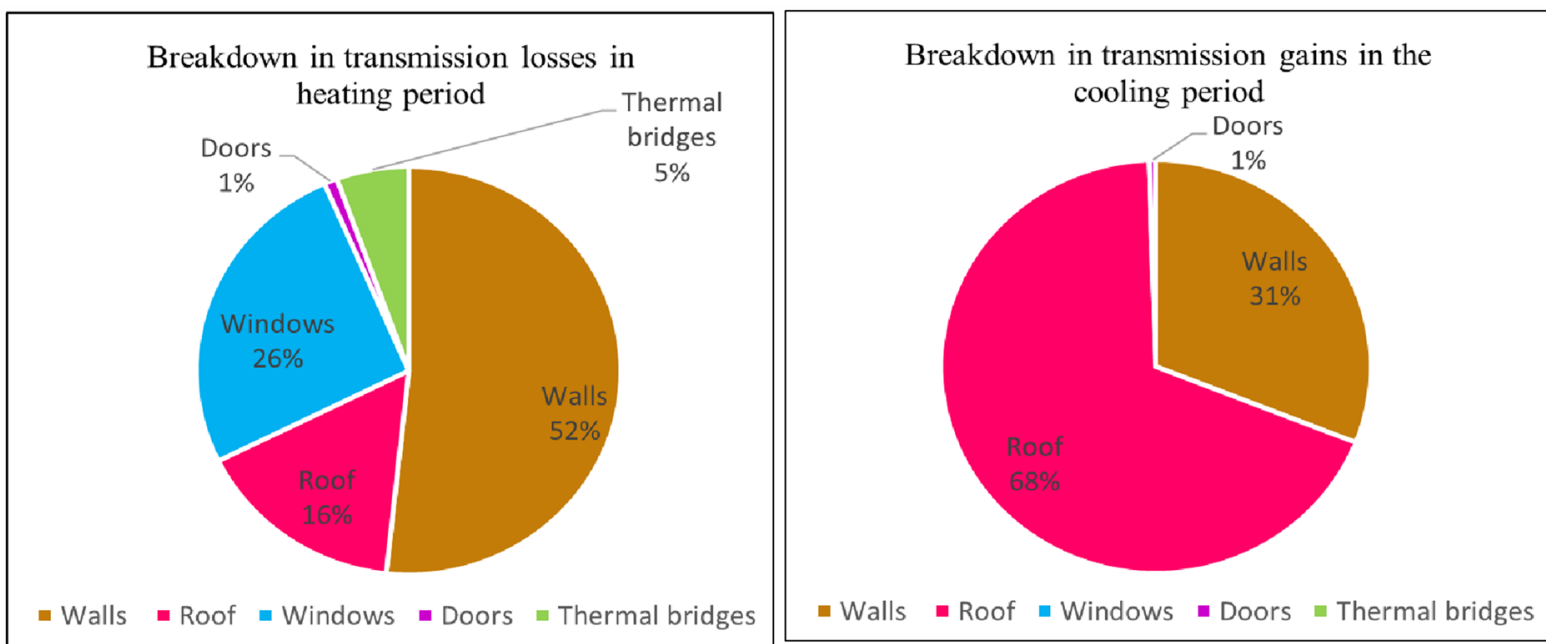

Fig. 9 Break-down of transmission losses in the heating period and transmission gains through the building envelope elements for the base case top floor apartment 1

shows the percentage of transmission losses in the heating period and transmission gains in the cooling period. The highest transmission loss during the heating period occurs through the walls, with over half of all losses, followed by the windows with $26 \%$ and then the roof by $16 \%$. Regarding the heat gain in the cooling period, the main source of heat gain is from the roof and then from the walls.

By analyzing the simulation results of the base case, it could be concluded that the walls roof, and windows account for a major part of the total heat loss and gains.

\section{Energy demand optimization strategies}

The most important passive strategies that have the potential to reduce the energy demand of the typical apartment building (base case) in Amman, Jordan are defined based on the simulation results in the previous section, also different scenarios of each strategy have been proposed to determine the best solution to minimize building energy demand. Although this research is mainly about passive strategies, installing energy-efficient lighting is also suggested to mainly reduce the building electricity demand. The proposed strategies are as follows:

\section{Strategy 1: walls insulation}

Adding thermal insulation to the external walls with different thicknesses (from 1 to $10 \mathrm{~cm}$ ) is investigated. The heat conductivity of the insulation is $0.67 \mathrm{~W} / \mathrm{m}^{2} \mathrm{~K}$.

\section{Strategy 2: roof insulation}

The effect of roof insulation is investigated, considering a thickness range from 1 to $10 \mathrm{~cm}$. The heat conductivity of the insulation is $0.67 \mathrm{~W} / \mathrm{m}^{2} \mathrm{~K}$.

\section{Strategy 3: window type}

The effect of replacing single-pane windows with $\mathrm{U}$-values of $5.92 \mathrm{~W} / \mathrm{m}^{2} \mathrm{~K}$ in the base case with two window types; double clear glazing windows with $\mathrm{U}$-value of $2.86 \mathrm{~W} / \mathrm{m}^{2} \mathrm{~K}$, and low-emission double glazing window with U-values of $1.59 \mathrm{~W} / \mathrm{m}^{2} \mathrm{~K}$, indifferent façade orientations are investigated in term of energy-saving potential.

\section{Strategy 4: shading device}

The current status of the apartment in the base case model is without any shading devices for windows. Horizontal overhang, vertical side-fins, and ventilated blind are the three proposed cases of shading devices. Overhang and side-fins are simulated with different projections, ranging from $20 \mathrm{~cm}$ and $140 \mathrm{~cm}$. While, the ventilation blinds are simulated with different operating strategies, as mentioned below:

- Case 1: "sun and schedule". In this case, during the cooling period from May to October, the ventilation blinds are down when the occupants are present in the zone and the sun penetrates through the windows. 
- Case 2: "day cooling". In this case, during the cooling period from May to October, the ventilation blinds are down during the day from 06:00 to 18:00.

- Case 3: "all day cooling". In this case, the ventilation blinds are down through all day in the cooling period from May to October.

- Case 4: "night heating". In this case, the ventilation blinds are down in the heating period from December to March during the night from 18:00 to 06:00.

\section{Strategy 5: natural ventilation}

In the base case, the windows are already assumed to be opened during the day when cooling is needed, and the outdoor temperature is lower than the indoor temperature. In addition to the day ventilation which is assumed in the base case, the natural ventilation strategy during the night and evening is proposed to reduce the cooling demand in cooling periods from May to October, different cases are proposed as mentioned below:

- Case 1: "bedrooms $2 \mathrm{~h}$ night ventilation", in this case, the windows are open during the cooling period from May to October in the bedrooms at the evening two hours before sleeping from 18:00 to 20:00, to avoid the undesirable flow of air during sleeping time.

- Case 2: "all night ventilation", windows are open in the living room, guest room, kitchen during the evening and night from 18:00 to 6:00.

- Case 3: include both case 1 and case 2 .

\section{Strategy 6: energy-efficient lighting}

LED light bulbs are proposed to replace the lighting bulbs in the base case. The used power of LED lighting bulbs is 12 W (ENERGY RATING 2018).

\section{Results and discussion}

In this section, the benefit of each strategy is assessed by comparing the annual energy demand simulation results before and after the implementation of each strategy separately, and then in combination with other strategies. Verifications of simulation models were carried out. There is considerable agreement between the current findings and those of some previous studies related to energy consumption in a residential building under a Mediterranean climate (Attia and Zawaydeh 2014; Bataineh and Alrabee 2018; Bataineh and Al Rabee 2021).

\section{Strategy 1: walls insulation}

Figure 10 illustrates the effect of the wall insulation thickness on the cooling and heating demands compared to the base case (no insulation) for top floor apartment 1 in a residential building in Amman, Jordan. It is obvious that higher insulation thickness leads to lower heating demand. However, most of the energy savings are achieved through the first $4 \mathrm{~cm}$ thickness, and after that, increasing the insulation thickness has no important impact on the heating demand, which proves that there is no need for huge insulation thicknesses. The wall insulation leads to lower cooling demand compared with the uninsulated case, but the reduction is not high as in the heating demands. Thus, it can be said that the use

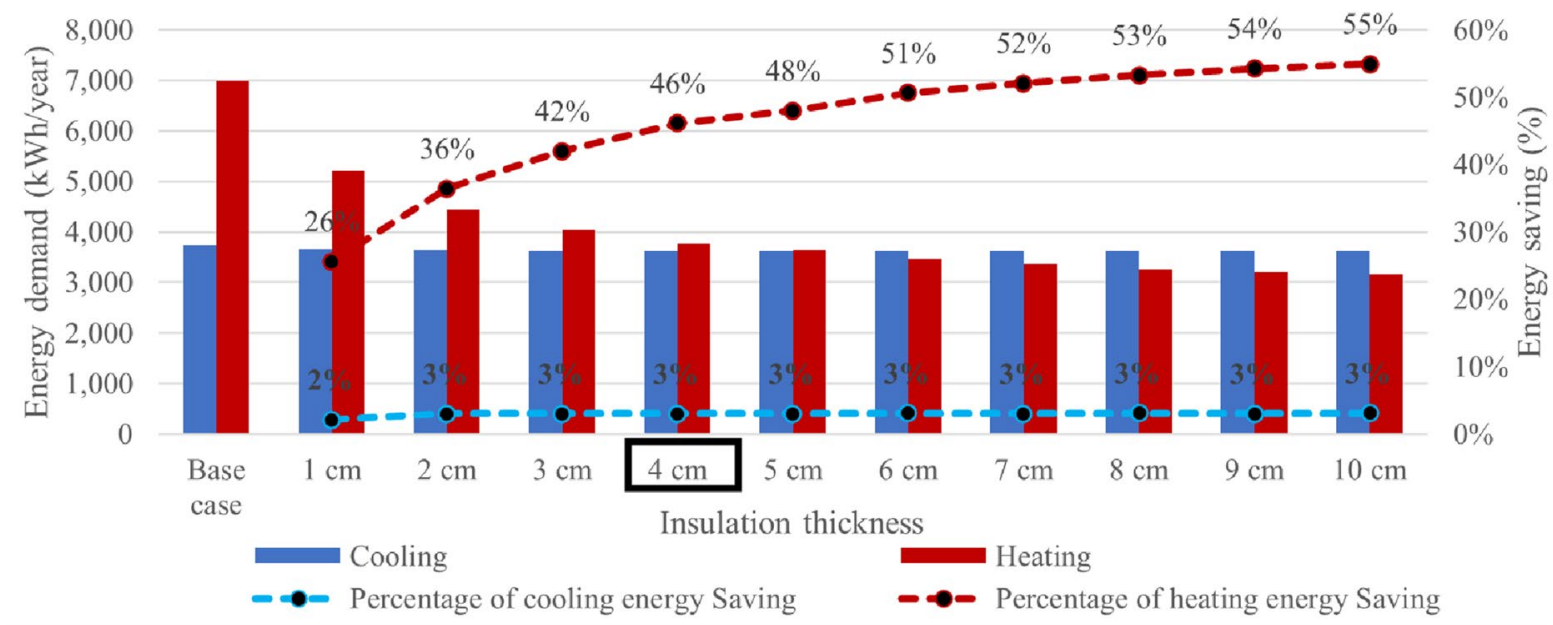

Fig. 10 The impact of thermal insulation thickness applied to the wall on heating and cooling energy demand for the top-floor apartment 1, and the energy-saving percentage in comparison with the base case model 


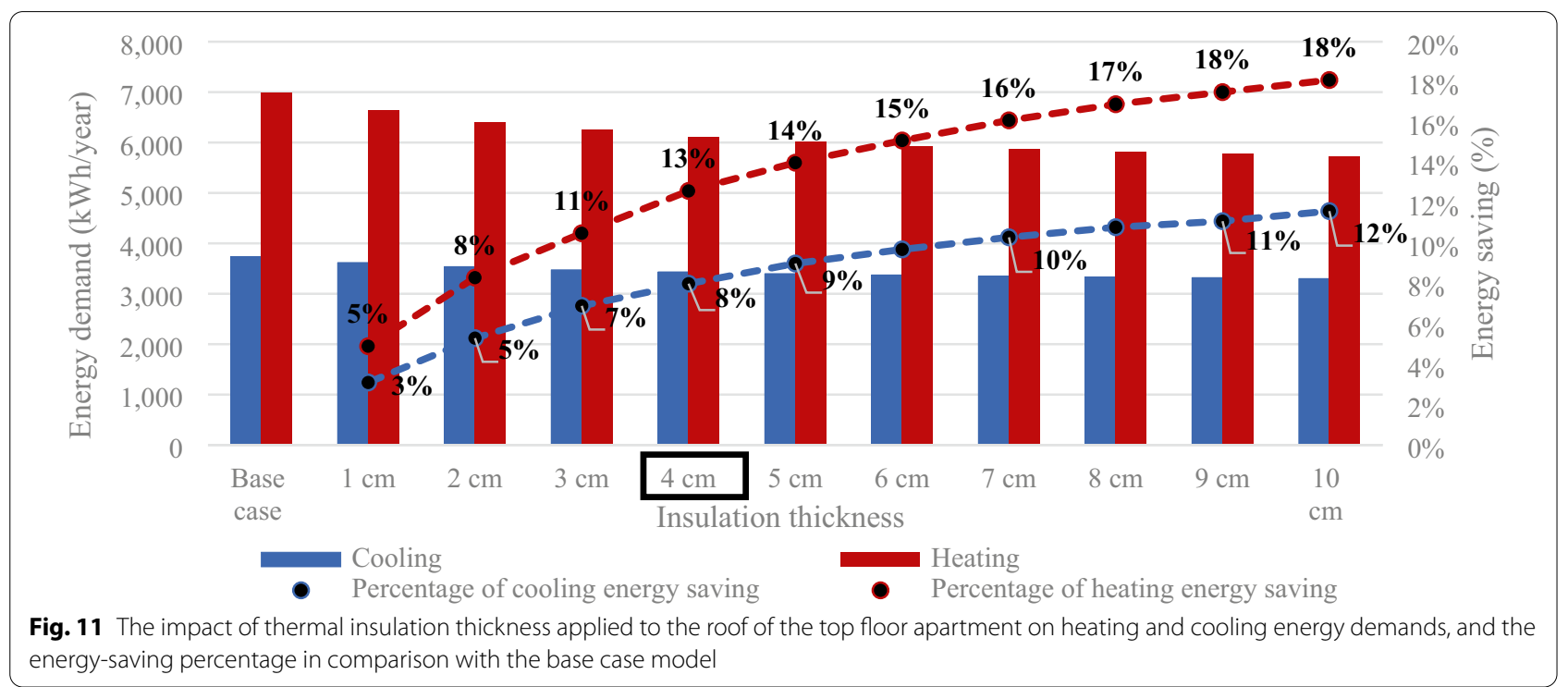

of insulation is more important for the reduction of the heating demand than the cooling demand.

Accordingly, with $4 \mathrm{~cm}$ insulation thickness the annual saved energy is about $46 \%$

and $3 \%$ in terms of total heating and cooling demand respectively, compared to the base case. This result is almost similar to the result of the research conducted by the researcher Attia and Zawaydeh (Attia and Zawaydeh 2014).

\section{Strategy 2: roof insulation}

Figure 11 demonstrates the effect of the roof insulation thickness on the annual energy demand of the base case apartment model. It can be stated that the roof insulation leads to lower heating and cooling demands compared with the base case (uninsulated case), the effect on the heating demand is higher than on the cooling demand, however, the roof insulation has a more significant impact on the total cooling energy demand than the wall insulation. Generally, insulation thickness over $4 \mathrm{~cm}$ has a low impact on the results. Accordingly, with $4 \mathrm{~cm}$ roof insulation thickness, the total saved energy is $13 \%$ and $8 \%$ for heating and cooling respectively.

\section{Strategy 3: window type}

Figures 12 and 13 illustrate the impact of installing double clear glazing windows and low-emission double glazing windows, respectively, with different orientations compared

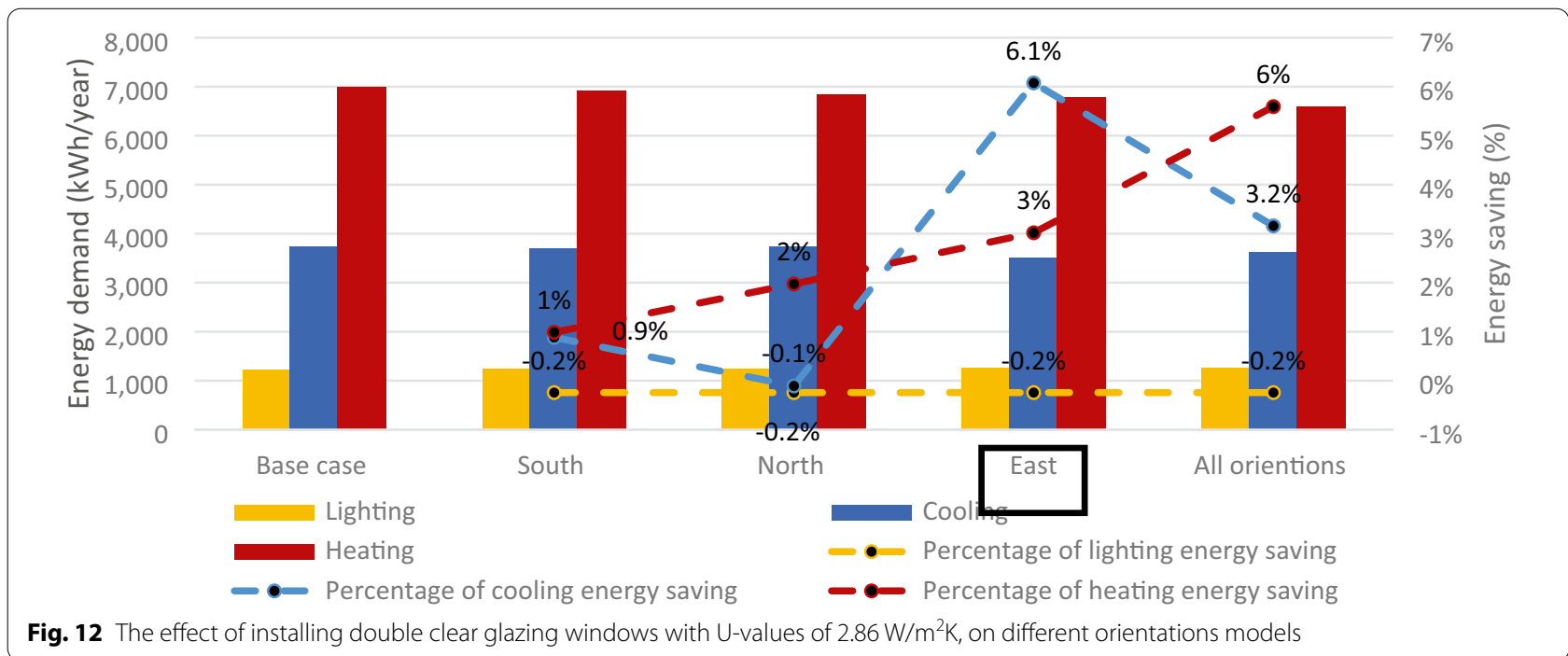




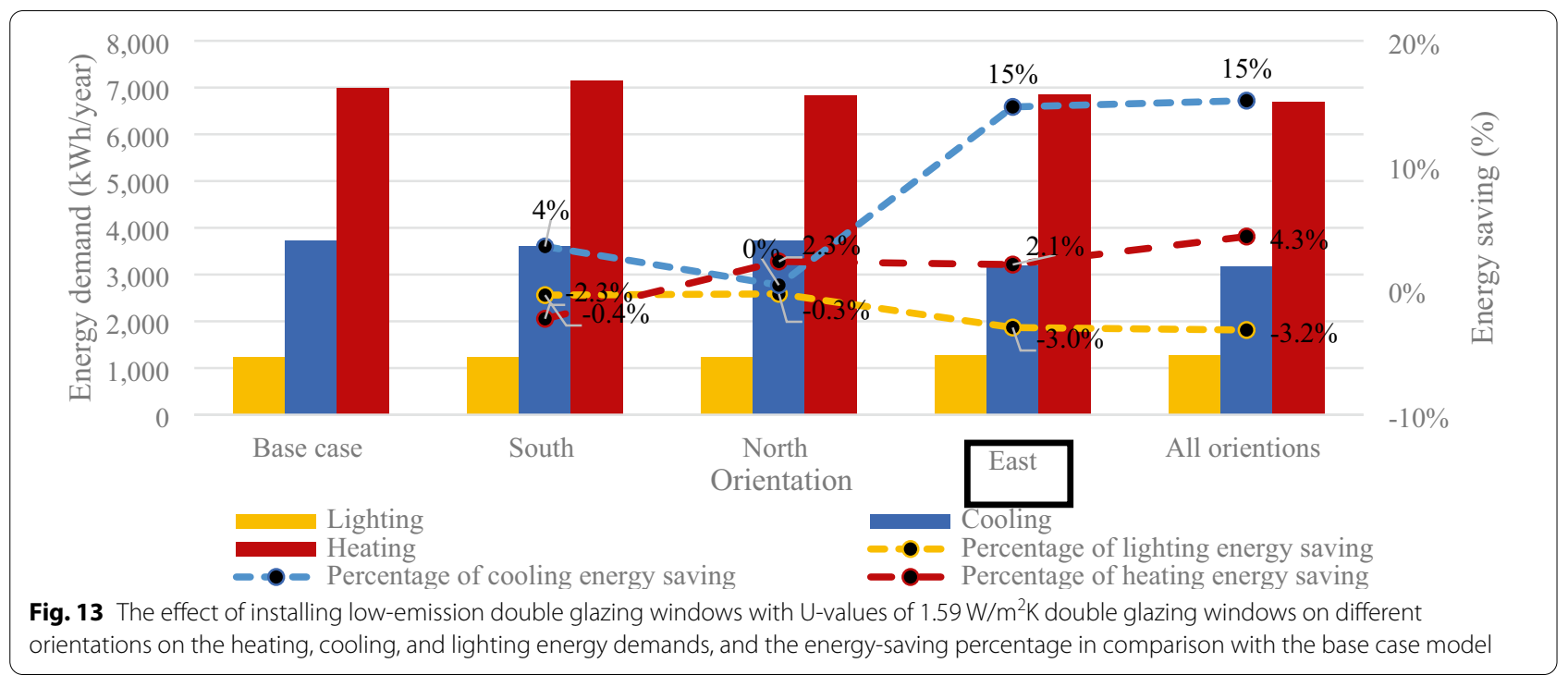

to the base case model (single glazed windows) in terms of annual energy demands. From the results, it can be noticed that both window types on the east orientation results in a higher heating and cooling demand saving than in the north and south orientations. In the eastern orientation cooling demand is reduced by $14.7 \%$ in the case of low-emission double glazing windows, and $6.1 \%$ in the case of double clear glazing windows, the heating is reduced by $2.1 \%$. In contrast, lighting demand is increased slightly, and it reaches its highest value in the east orientation by $3.2 \%$.

\section{Strategy 4: shading device}

Figures 14 and 15 illustrate the annual energy demands of the multi-family apartment with overhangs on the south orientation and side-fines on the east orientation of different sizes and compared with the same building without shading devices (base case). Generally, both overhang shading devices on south-facing windows and side-fines on the east-facing windows reduce the cooling energy demand and increase the heating and lighting energy demands. Increasing the size of the shading devices increase this effect. However, the increase in heating energy demand is more than reducing the cooling energy demand of the building. Therefore, using the overhang for south-facing windows and side-fins for east-facing windows will increase the total energy demand.

Regarding the ventilation blinds, for south and east-facing windows, movable ventilation blinds have more effect on the energy demands, when it is correctly controlled by users, see Fig. 16 and Fig. 17. In case 1, case 2, and case 3 the ventilation blind is kept down during the heating period; therefore, these cases do not affect the heating demand, however, the cooling demand is decreased with the highest saving in case 2 when the ventilated blind is kept down during all day in the cooling period. In case 2, the cooling energy decreased by $4.3 \%, 17 \%$ for south and east-facing windows, respectively, compared to the base case. In case 4, the ventilation blinds are down during the night (from 18:00 to 6:00) during the heating period. In this case, the heating demand is reduced by $1 \%$ and $4.3 \%$ for south and east-facing windows respectively in comparison with not having any shading device. Regarding the lighting energy demand, ventilation blinds on the south elevation have a neglected effect, however, in the east elevation the lighting energy demand reduced by $3.7 \%$ in case 2 and $4.3 \%$ in case 3 .

Based on the findings of the shading device simulation, "day cooling" and "night heating" operation strategies are used in this paper for both south and east-facing windows.

\section{Strategy 5: natural ventilation}

In the base case, natural ventilation is used during the day when cooling is needed, and the outdoor temperature is lower than the indoor temperature. Figure 18 below, illustrates the effect of night ventilation with different schedules in comparison with the base case (daytime ventilation) in the cooling period. In case 1 , when the windows are open in the bedrooms, two hours in the evening, the cooling demand decrease by $1 \%$. While in case 2, when the windows are open during the night in the living room, guest room, and kitchen, the cooling demand decrease by $13.9 \%$ compared to the base case. If these two ventilation schedules are applied together (case 3 ), the total saving of cooling energy reaches $14.6 \%$. 


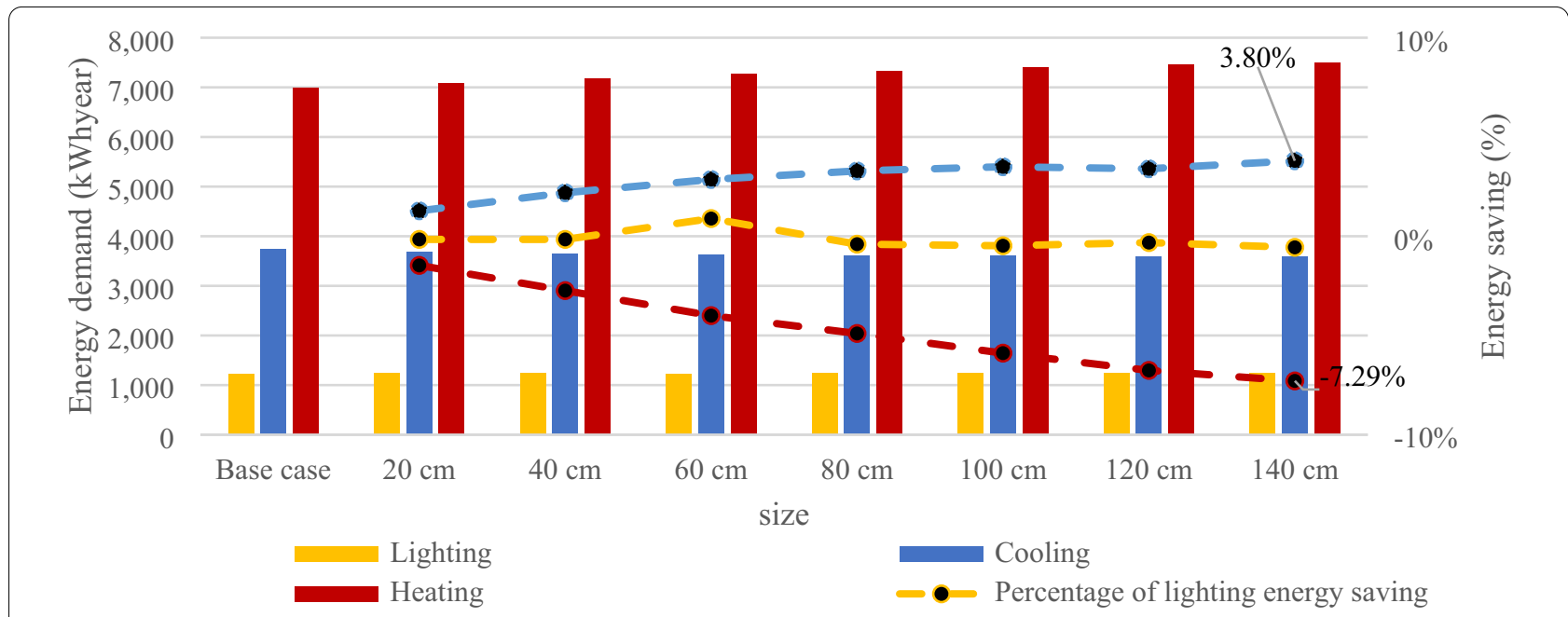

Fig. 14 The effect of overhang with a different projection on the south elevation on the heating, cooling, and lighting energy demands, and the energy-saving percentage in comparison with the base case model

\section{Strategy 6: energy-efficient lighting fixtures}

When all the light bulbs in the base case are replaced by LED bulbs the total annual lighting is reduced significantly by $75 \%$. Moreover, the use of LED bulbs generates less of an internal load from light-waste-heat, which results in reducing the cooling demand by $3.2 \%$ and increasing the heating demand by $4.7 \%$ compared to the base case, as illustrated in Fig. 19. However, the increase in heating demand is neglected in comparison with the lighting energy-saving potential.

\section{Combinations of all strategies}

In this section, the best design of all the previously investigated strategies is selected and simulated in combination with each other to find out the best final proposed design for the multi-family building in Amman Jordan. The cases simulated in this section are:

- Case 1: add $4 \mathrm{~cm}$ wall insulation to the base case model.

- Case 2: case $1+$ adding $4 \mathrm{~cm}$ roof insulation.

- Case 3: case 2+ double glazing windows on east and north elevations.

- Case 4: case 3+ventilation blind on the south and east elevations with "day cooling" and "night heating" operation strategies.

- Case 5: case 4+night ventilation ("bedrooms $2 \mathrm{~h}$ night ventilation" and "all night ventilation" strategies)

- Case 6: case 5+ energy-efficient LED lighting bulbs.
The optimized case, as shown in Fig. 20, reaches a lower annual energy demand than the base case by 55,64 and $82 \%$ for cooling, heating, and lighting respectively. The simulation results show that the wall insulation alone achieves $46 \%$ out of $64 \%$ of heating energy saving, while the other parameters impact energy reduction by $18 \%$. The lowest impact rate is related to the energy-efficient light bulbs, which increase the heating demand by $4 \%$. However, the lighting demand is decreased significantly by $82 \%$. Regarding the cooling demand, the saved energy is achieved by combining different parameters, the most effective are double glazing windows, ventilation blinds, and night ventilation strategies. There is considerable agreement between the findings in this study and the research conducted by Attia and Zawaydeh, as they found that the energy used in the residential buildings under Jordan climate can be reduced up to $66 \%$ by combining different passive designs strategies (Attia and Zawaydeh 2014). Figure 21 illustrates the energy demand for the multi-family building before and after implementing the suggested passive strategies. The total annual energy demands for all the apartments in the improved residential building are $12,807 \mathrm{kWh} /$ year for cooling, $17,160 \mathrm{kWh} /$ year for heating, and 37,300 kWh/year electricity for equipment and lighting.

\section{Conclusion}

Detailed simulation analyses have been conducted to investigate the effect of different passive design strategies on the energy demand of the typical multi-family 

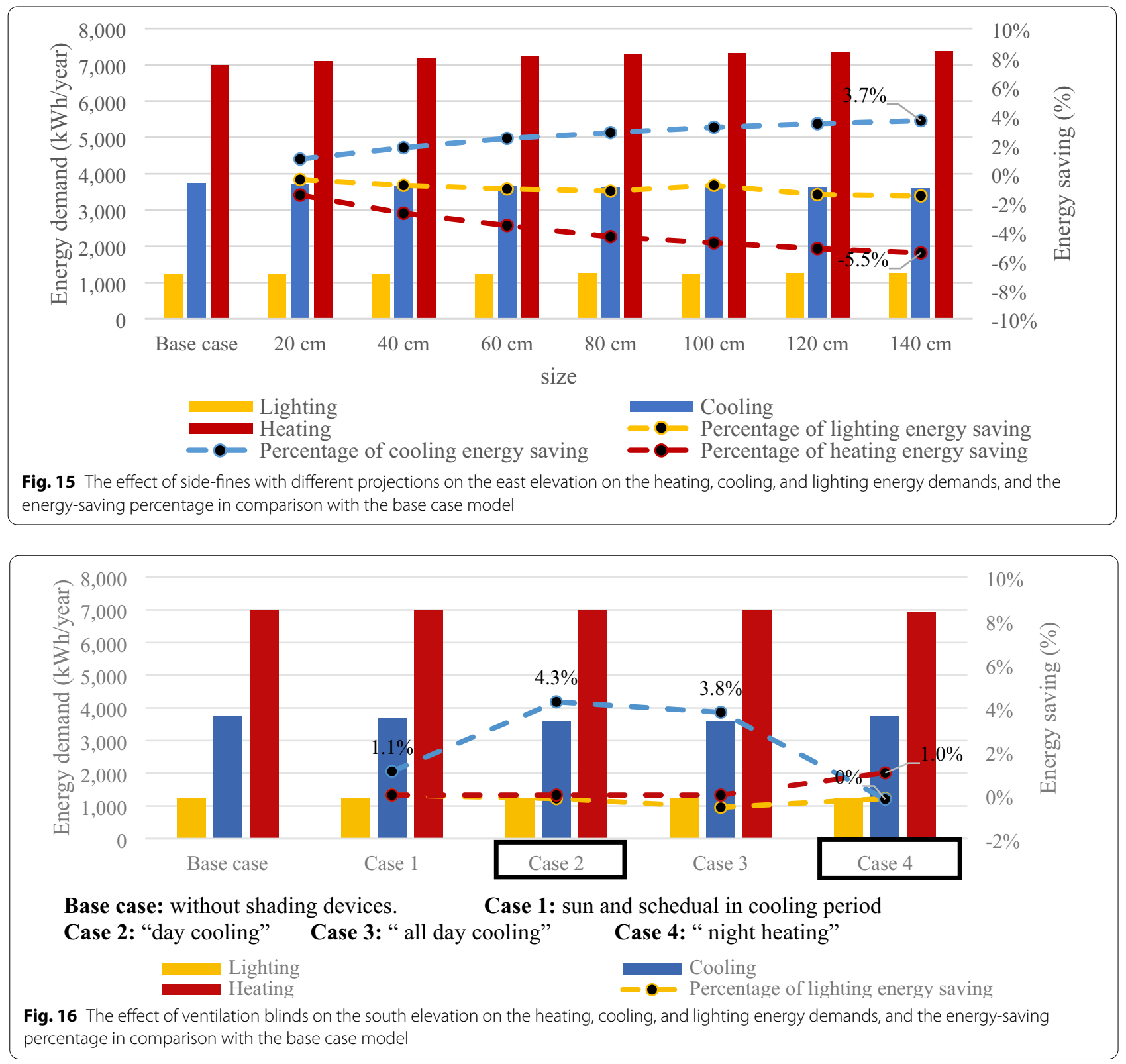

buildings in Amman, Jordan. Starting with the description of the base case model input data, then the energy demand results for the base scenario were examined. After that, several strategies have been applied to the base case. These strategies include wall and roof insulation, window type, shading, natural ventilation, and lighting system. The effect of each strategy on the building energy demand is investigated and compared to the base case alone and then in combination with the other strategies, to find the optimum solution to reduce the energy demand of the base case simulated building. The study's key findings showed that several passive design strategies can be used to design energy-efficient multifamily buildings under a Mediterranean climate. One of the most significant aspects of energy saving is the installation of proper thickness wall and roof insulation, the results show that around $45 \%$ savings of the heating demand are achieved due to adding wall insulation. Regarding the cooling demand about 17 and $14 \%$ are saved due to applying a ventilated blind shading device and using a nighttime ventilation strategy, respectively. Moreover, y combining the best strategy, the building's annual energy demand could be significantly reduced. The potential saving in energy is up to 53,71 , and $78 \%$ of the annual 


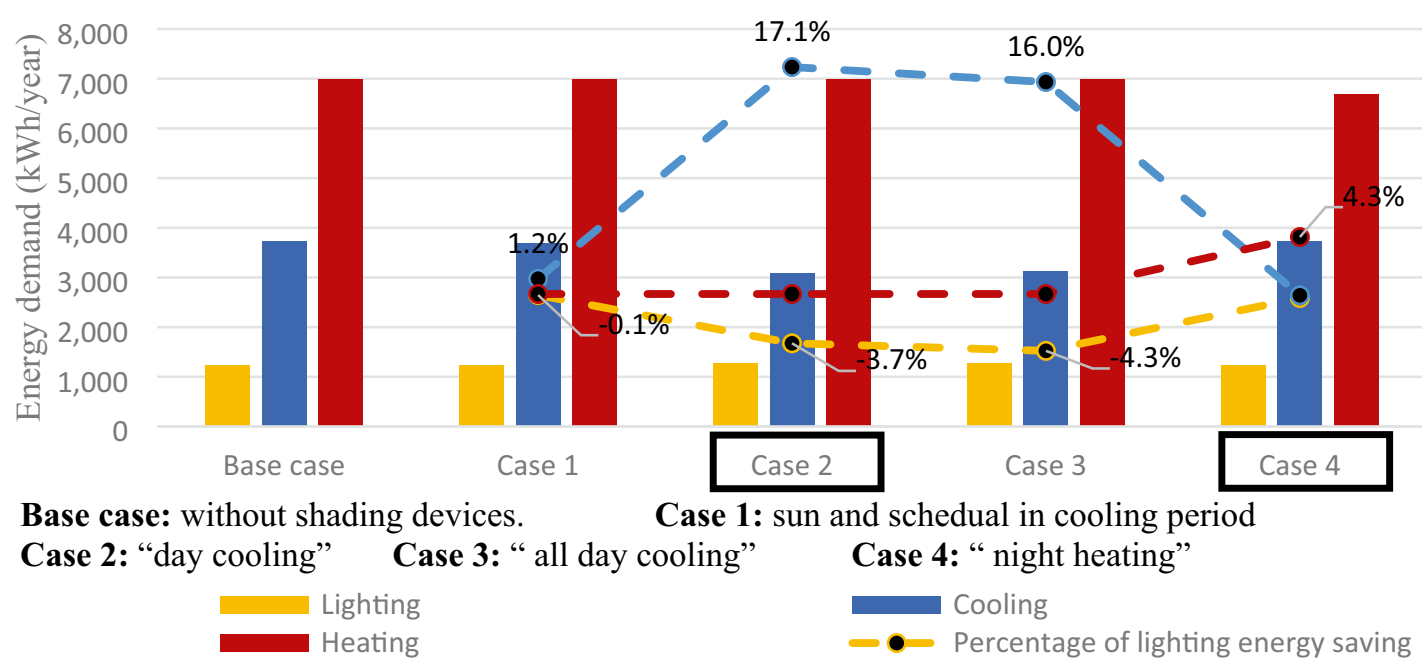

Fig. 17 The effect of ventilation blinds on the east elevation on the heating, cooling, and lighting energy demands, and the energy-saving percentage in comparison with the base case model

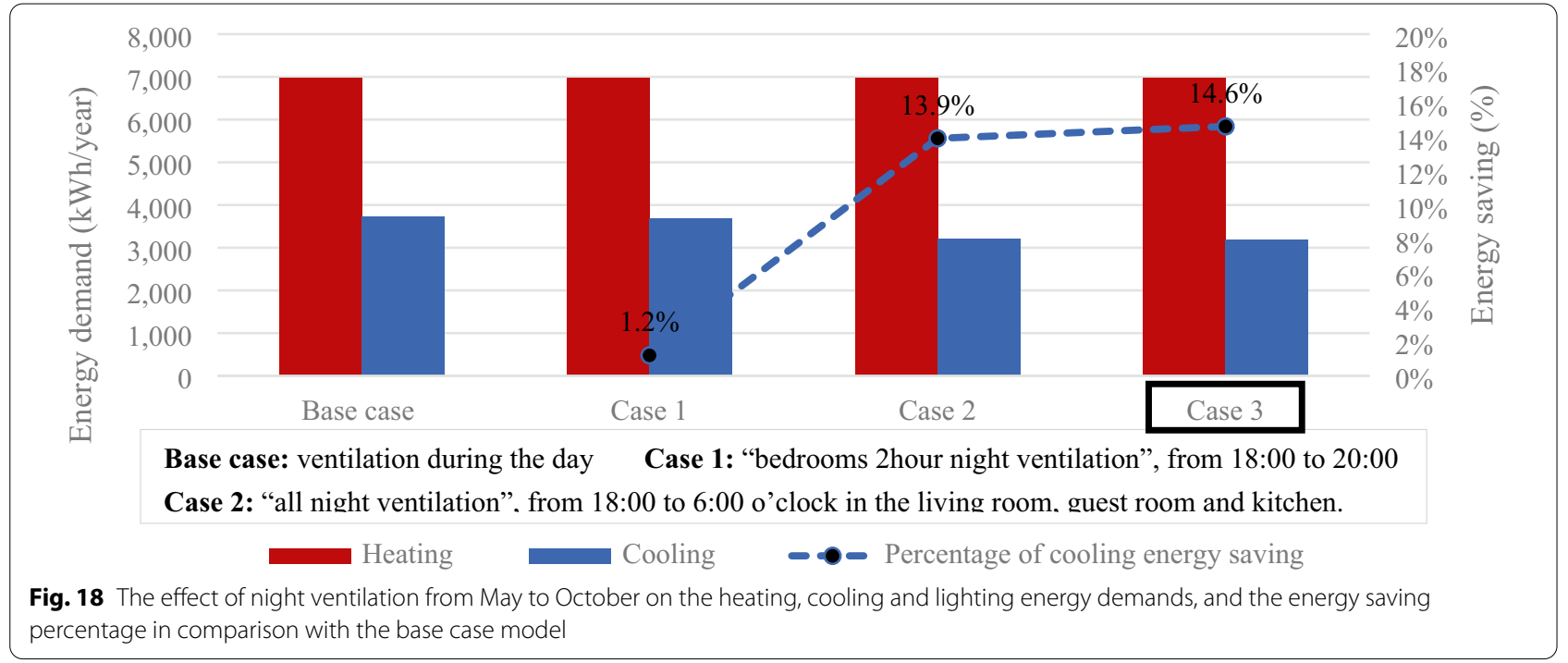

cooling, heating, lighting demands respectively, in comparison with the typical multifamily buildings.

The findings of this study will be useful to energy policymakers, architects, engineers, and academics interested in residential energy demand. This study raises awareness regarding the current status of multifamily buildings' energy demand and allows architects and building designers to inform their decision-making regarding passive design strategy effectiveness. The study findings are helpful to create a new guide for energy-efficient design in Jordan. In the long term, the presented results can further lead to the improvements of building codes considering passive design measures. Furthermore, it is strongly advised to include these investigations and outcomes into academic curricula in Jordanian architectural design institutions to avoid future architects making the same mistakes.

A similar methodology used in this study could be applied to residential buildings in different climate zones and different typologies to investigate their applicability. Moreover, as this study is only limited to passive design strategies, future research can be extended to include active design strategies while considering other influencing factors in the selection of the optimal design solutions such as life cycle cost and environmental effect. 


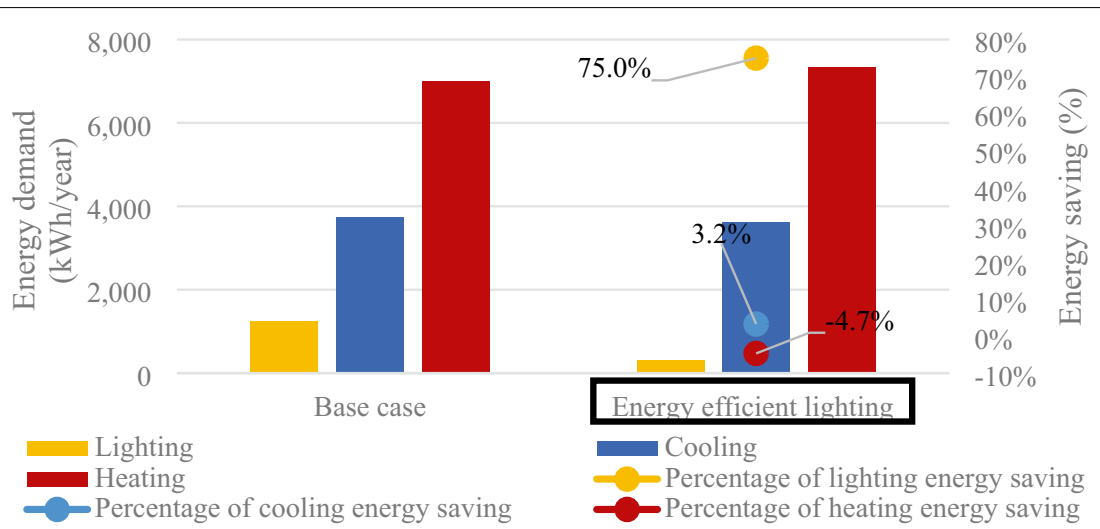

Fig. 19 The effect of installed energy-efficient light LED bulbs on the energy demands and the energy-saving percentage in comparison with the base case model

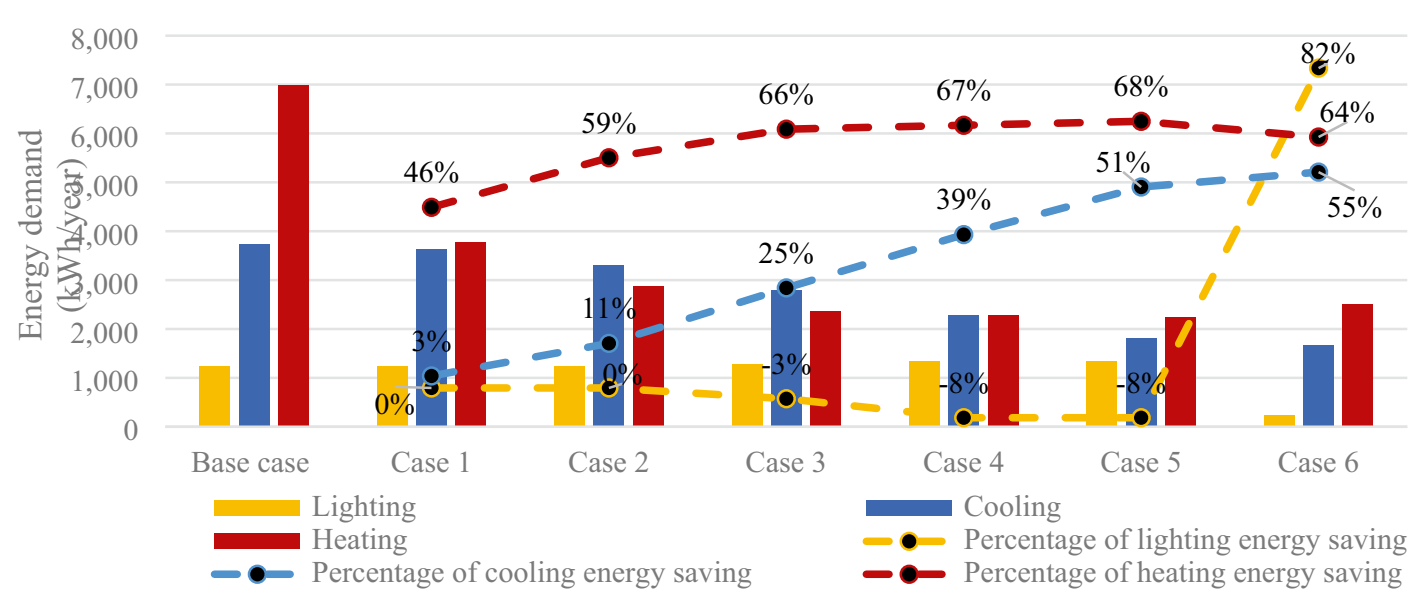

Fig. 20 Annual energy demands for different energy-saving strategies and the energy-saving percentage in comparison with the base case apartment building in Amman, Jordan
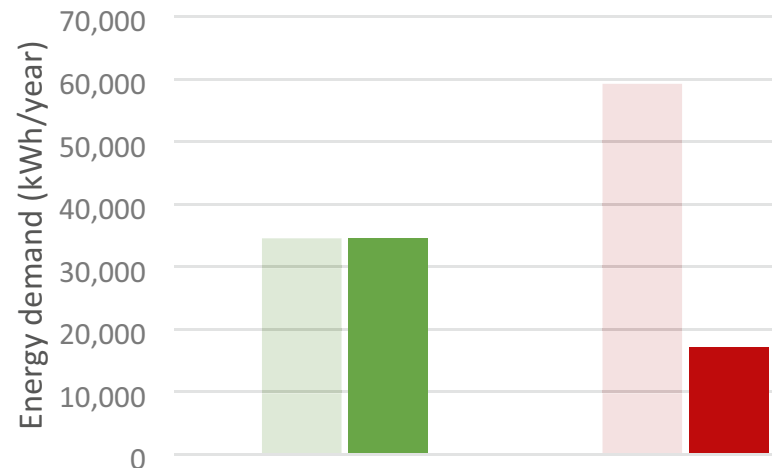

Equipment

Heating

Base case apartment building Improved apartment building

$$
\begin{aligned}
& \text { Equipment } \quad \text { Heating } \square \text { Cooling } \square \text { Lighting } \\
& \text { Equipment } \quad \text { Heating Cooling Lighting }
\end{aligned}
$$

Fig. 21 Energy demand of the improved apartment building in comparison to the base case apartment building, in Amman, Jordan 


\section{Acknowledgements}

The authors would like to acknowledge Professor Christoph Nytsch-Geusen from Berlin University of the Arts, for his patient guidance, enthusiastic encouragement, and useful critiques of this research work.

\section{Authors' contributions}

The first author conducted the research, while the other authors were involved in writing the manuscript and have ensured quality standards and rewritten the entire findings. CN-G supervised this research as a part of Ph.D. thesis. All authors read and approved the final manuscript.

\section{Funding}

The authors state that this work has not received any funding.

\section{Availability of data and materials}

The datasets used and/or analyzed during the current study are available from the corresponding author on reasonable request.

\section{Declarations}

\section{Competing interests}

The authors declare they have no competing interests.

\section{Author details}

'Department of Architecture Engineering, Faculty of Engineering, Mutah University, P.O Box 7, Al-Karak 61710, Jordan. ${ }^{2}$ Mechanical Engineering Department, Faculty of Engineering, Mutah University, P.O Box 7, Al-Karak 61710, Jordan. ${ }^{3}$ Institute of Architecture and Urban Development, University of the Arts Berlin, 10623 Berlin, Germany.

Received: 21 December 2021 Accepted: 7 February 2022

Published online: 05 March 2022

\section{References}

Al-Hinti I, Al-Sallami H (2017) Potentials and barriers of energy saving in Jordan's residential sector through thermal insulation. Jordan J Mech Indust Eng 11(3):141-145

Ali $\mathrm{HH}$ et al (2020) Evaluation of near-net-zero-energy building strategies: a case study on residential buildings in jordan. IJEEP 10(6):325-336. https:// doi.org/10.32479/ijeep.10107

Alnsour JA (2016) Managing urban growth in the city of Amman, Jordan. Cities 50:93-99. https://doi.org/10.1016/j.cities.2015.08.011

Alrwashdeh SS (2018a) Investigation of the energy output from PV racks based on using different tracking systems in Amman-Jordan. IJMET 9(10):687-694

Alrwashdeh SS (2018b) Modelling of operating conditions of conduction heat transfer mode using energy 2D simulation. Int J Online Eng 14(9):200207. https://doi.org/10.3991/ijoe.v14i09.9116

Alrwashdeh SS, Alsaraireh FM (2018) Wind energy production assessment at different sites in Jordan using probability distribution functions. ARPN J Eng Appl Sci 13(20):8163-8172

Al-Salaymeh A et al (2010) Technical and economical assessment of the utilization of photovoltaic systems in residential buildings: the case of Jordan. Energy Convers Manage 51(8):1719-1726. https://doi.org/10.1016/j. enconman.2009.11.026

ASHRAE (2004) ANSI/ASHRAE Standard 55-2004. Thermal Environmental Conditions for Human Occupancy SECTION. American Society of Heating Refrigerating and Air-Conditioning Engineers, Atlanta

ASHRAE (2016) 'ASHRAE Standard 62.2-2016: Ventilation and Acceptable Indoor Air Quality in Residential Buildings'. American Society of Heating, Refrigerating and Air-Conditioning Engineers, Inc., Atlanta, GA

Attia S, Al-Khuraissat M (2016) Life Cycle Costing for a Near Zero Energy Building in Jordan Initial Study, in The 5th Architectural Jordanian International Conference. Amman, Jordan

Attia S, Zawaydeh S (2014) Strategic Decision Making For Zero Energy Buildings in Jordan, International Conference on Energy and Indoor Environment for Hot Climates, pp 73-81
Awadallah T (2015) Role of street-level outdoor thermal comfort in minimizing urban heat island effect by using simulation program, envi-met : case of Amman, Jordan. RJEES 7(3):42-49

Baranda PB, Sartori I (2014) Cost optimality of energy systems in zero emission buildings in early design phase. NTNU-Norwegian University of science and technology, Norway

Bataineh K, Al Rabee A (2021) Design optimization of energy efficient residential buildings in Mediterranean region. J Sustain Dev Energy Water Environ Syst. https://doi.org/10.13044/j.sdewes.d9.0385

Bataineh K, Alrabee A (2018) Improving the energy efficiency of the residential buildings in jordan. Buildings 8:85. https://doi.org/10.3390/buildings8 070085

Cabeza LF et al (2010) Experimental study on the performance of insulation materials in Mediterranean construction. Energy Build 42(5):630-636. https://doi.org/10.1016/j.enbuild.2009.10.033

CIBSE (2006) Guide a: environmental design. Chartered Institution of Building Services Engineers, London

CIBSE (2013) Lighting for Communal Residential Buildings-LG9. Chartered Institution of Building Services Engineers. http://www.pioneerlighting. $\mathrm{com} /$ new/pdfs/IESLuxLevel.pdf.

Cornaro C et al (2017) Validation of a PCM simulation tool in IDA ICE dynamic building simulation software using experimental data from Solar Test Boxes. Building Simulation Applications

Department of Statistics (2016) Population and housing census. Department of Statistics, Jordan. https://doi.org/10.1017/CBO9781107415324.004

El-Darwish I, Gomaa M (2017) Retrofitting strategy for building envelopes to achieve energy efficiency. Alex Eng J 56(4):579-589. https://doi.org/10. 1016/j.aej.2017.05.011

Energy Rating (2018) Light bulb buying quide, E3 Equipment Energy Efficiency. http://www.energyrating.gov.au/sites/new.energyrating/files/ documents/factsheet_light_bulb_buying_guide_1.pdf. Accessed 15 Feb 2019

EQUA Simulation AB (2010a) Validation of IDA Indoor Climate and Energy 4.0 build 4 with respect to ANSI/ASHRAE Standard 140-2004. http://www. equaonline.com/iceuser/validation/ASHRAE140-2004.pdf. Accessed 15 Dec 2021

EQUA Simulation AB (2010b) Validation of IDA Indoor Climate and Energy 4.0 with respect to CEN Standards EN 15255-2007 and EN 15265-2007. http://www.equaonline.com/iceuser/validation/CEN_VALIDATION_EN_ 15255 AND_15265.pdf. Accessed 15 Dec 2021

EQUA (2018) 'Getting Started with IDA Indoor Climate and Energy', EQUA Simulation $A B$

Friess WA, Rakhshan K (2017) A review of passive envelope measures for improved building energy efficiency in the UAE. Renew Sust Energ Rev 72:485-496. https://doi.org/10.1016/j.rser.2017.01.026

Hassouneh K, Al-Salaymeh A, Goussous J (2014) Energy audit, an approach to apply the concept of green building for a building in Jordan. Sustain Cities Soc. https://doi.org/10.1016/j.scs.2014.08.010

$\mathrm{He} \mathrm{Q}$ et al (2019) Energy-efficient window retrofit for high-rise residential buildings in different climatic zones of China. Sustainability (switzerland). https://doi.org/10.3390/su11226473

Hee WJ et al (2015) The role of window glazing on daylighting and energy saving in buildings. Renew Sustain Energy Rev 42:323-343. https://doi.org/ 10.1016/j.rser.2014.09.020

Hesaraki A, Holmberg S (2013) Energy performance of low temperature heating systems in five new-built swedish dwellings: a case study using simulations and on-site measurements. Build Environ 64:85-93. https:// doi.org/10.1016/j.buildenv.2013.02.009

IEA (2017) Energy access outlook 2017: from poverty to prosperity. Int Energy Agency. https://doi.org/10.1787/9789264285569-en

Jaber S, Ajib S (2011) Thermal and economic windows design for different climate zones. Energy Build. 43(11):3208-3215. https://doi.org/10.1016/j. enbuild.2011.08.019

Jaber J et al (2008) Evaluation of conventional and renewable energy sources for space heating in the household sector. Renew Sustain Energy Rev 12:278-289. https://doi.org/10.1016/j.rser.2006.05.004

Jäger J et al (2012) Stone and Architecture: In the Mountainous Regions of Jordan and Syria. Berlin DAAD c 2012 
Johansson E et al (2009) Climate conscious architecture and urban design in Jordan-towards energy efficient buildings and improved urban microclimate. Jordan

Karlsson F, Rohdin P, Persson ML (2007) Measured and predicted energy demand of a low energy building: Important aspects when using building energy simulation. Build Serv Eng Res Technol 28(3):223-235. https:// doi.org/10.1177/0143624407077393

Koo C et al (2017) Development of the smart photovoltaic system blind and its impact on net-zero energy solar buildings using technical-economicpolitical analyses. Energy 124(February):382-396. https://doi.org/10 1016/j.energy.2017.02.088

La Fleur L, Moshfegh B, Rohdin P (2017) Measured and predicted energy use and indoor climate before and after a major renovation of an apartment building in Sweden. Energy Build. 146:98-110. https://doi.org/10.1016/j. enbuild.2017.04.042

Lambie E, Saelens D (2020) Identification of the building envelope performance of a residential building: a case study. Energies 13(10):1-28. https://doi.org/10.3390/en13102469

Lau AKK et al (2016) Potential of shading devices and glazing configurations on cooling energy savings for high-rise office buildings in hot-humid climates: the case of Malaysia. Int J Sustain Built Environ 5(2):387-399. https://doi.org/10.1016/j.ijsbe.2016.04.004

Liu L et al (2014) Comprehensive investigation on energy retrofits in eleven multi-family buildings in Sweden. Energy Build 84:704-715. https://doi. org/10.1016/j.enbuild.2014.08.044

Liu L, Rohdin P, Moshfegh B (2015) Evaluating indoor environment of a retrofitted multi-family building with improved energy performance in Sweden. Energy Build. 102:32-44. https://doi.org/10.1016/j.enbuild.2015.05.021

Liu X, Chen X, Shahrestani M (2020) Optimization of insulation thickness of external walls of residential buildings in hot summer and cold winter zone of China. Sustainability (switzerland) 12(4):1-21. https://doi.org/10 3390/su12041574

MEMR (2017) Energy annual report. MEMR, Jordan

MEMR (2018) Energy 2018 - facts \& figures. MEMR, Jordan

Milić V, Ekelöw K, Moshfegh B (2018) On the performance of LCC optimization software OPERA-MILP by comparison with building energy simulation software IDA ICE. Build Environ 128:305-319. https://doi.org/10.1016/j. buildenv.2017.11.012

Molin A, Rohdin P, Moshfegh B (2011) Investigation of energy performance of newly built low-energy buildings in Sweden. Energy Build. 43(10):28222831. https://doi.org/10.1016/j.enbuild.2011.06.041

Nadel S (2002) Appliance and equipment efficiency standards. Annu Rev Energy Env 27(1):159-192. https://doi.org/10.1146/annurev.energy.27. 122001.083452

NEPCO (2016) National electric power company, annual report. NEPCO, Jordan Prieto A et al (2017) Solar coolfacades: framework for the integration of solar cooling technologies in the building envelope. Energy 137:353-368. https://doi.org/10.1016/j.energy.2017.04.141

Ragab A (2021) Investigating the impact of different glazing types on the energy performance in hot arid climate investigating the impact of different glazing types on the energy performance in hot arid climate ayman ragab. JAET. https://doi.org/10.21608/jaet.2021.96026.1121

RSS (2007) Climatic design of buildings and urban areas; advanced training programme. Royal Scientific Society, Jordan and Lund University, Sweden

Ryan EM, Sanquist TF (2012) Validation of building energy modeling tools under idealized and realistic conditions. Energy Build. 47:375-382. https:// doi.org/10.1016/j.enbuild.2011.12.020

Vadiee A, Dodoo A, Gustavsson L (2018) A comparison between four dynamic energy modeling tools for simulation of space heating demand of buildings. Cold Clim HVAC 2018:701-711. https://doi.org/10.1007/978-3-03000662-4_59

Younis, A. (2017) Towards resilient low-middle income apartments in amman, Jordan: a thermal performance investigation of heating load, in CIBSE ASHRAE Technical Symposium. Loughborough, UK.

Yu J et al (2011) Optimum insulation thickness of residential roof with respect to solar-air degree-hours in hot summer and cold winter zone of china. Energy Build. 43(9):2304-2313. https://doi.org/10.1016/j.enbuild.2011. 05.012

Zinzi M et al (2017) Experimental characterization and energy performances of multiple glazing units with integrated shading devices. Energy Procedia 113:1-8. https://doi.org/10.1016/j.egypro.2017.04.002

\section{Publisher's Note}

Springer Nature remains neutral with regard to jurisdictional claims in published maps and institutional affiliations.

\section{Submit your manuscript to a SpringerOpen ${ }^{\circ}$ journal and benefit from:}

- Convenient online submission

- Rigorous peer review

- Open access: articles freely available online

- High visibility within the field

- Retaining the copyright to your article

Submit your next manuscript at $\boldsymbol{\nabla}$ springeropen.com 